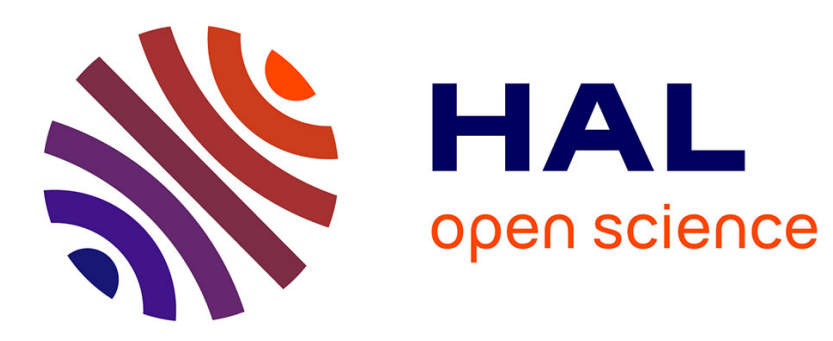

\title{
In vitro interaction and biocompatibility of titanate nanotubes with microglial cells
}

S. Sruthi, A. Loiseau, J. Boudon, F. Sallem, Lionel Maurizi, P.V. Mohanan, G. Lizard, N. Millot

\section{- To cite this version:}

S. Sruthi, A. Loiseau, J. Boudon, F. Sallem, Lionel Maurizi, et al.. In vitro interaction and biocompatibility of titanate nanotubes with microglial cells. Toxicology and Applied Pharmacology, 2018, 353, pp.74-86. 10.1016/j.taap.2018.06.013 . hal-02163529

\section{HAL Id: hal-02163529 \\ https://hal.science/hal-02163529}

Submitted on 9 Mar 2021

HAL is a multi-disciplinary open access archive for the deposit and dissemination of scientific research documents, whether they are published or not. The documents may come from teaching and research institutions in France or abroad, or from public or private research centers.
L'archive ouverte pluridisciplinaire HAL, est destinée au dépôt et à la diffusion de documents scientifiques de niveau recherche, publiés ou non, émanant des établissements d'enseignement et de recherche français ou étrangers, des laboratoires publics ou privés. 


\section{In vitro interaction and biocompatibility of titanate nanotubes with}

2 microglial cells

3 S. Sruthi ${ }^{1,2}$, A. Loiseau ${ }^{2}$, J. Boudon ${ }^{2}$, F. Sallem ${ }^{2}$, L. Maurizi ${ }^{2}$, P.V.

4 Mohanan $^{1}$, G. Lizard ${ }^{3 *}$, N. Millot ${ }^{2 *}$

$5{ }^{1}$ Toxicology Division, Biomedical Technology Wing, Sree Chitra Tirunal Institute for

6 Medical Sciences and Technology, Thiruvananthapuram - 695 012, Kerala, India

$7 \quad{ }^{2}$ Nanosciences Department, Laboratoire Interdisciplinaire Carnot de Bourgogne, UMR

86303 CNRS/Université Bourgogne Franche-Comté, 9 av. A. Savary, BP 47 870, 21078

9 Dijon, France

$10{ }^{3}$ Faculté des Sciences Gabriel, Laboratoire Bio-PeroxIL, EA7270, Université

11 Bourgogne Franche-Comté /Inserm, 6, Bd Gabriel, 21000 Dijon, France

$13 *$ corresponding authors:

14 Nadine.Millot@u-bourgogne.fr and Gerard.Lizard@ u-bourgogne.fr

15 Abstract

16 Titanate nanotubes (TiONts) are promising agents for biomedical applications. Microglial

17 activation and associated oxidative burst are major challenges in drug delivery applications

18 across the brain. Here, TiONts were designed for drug delivery systems by functionalizing them

19 with (3-aminopropyl) triethoxysilane (APTES), their interactions and biocompatibility were

20 studied in vitro using murine microglial BV-2 cells. TiONts-APTES exposure resulted in

21 increased ROS production and transient mitochondrial hyperpolarization. However, there was 
no indication of microglial proliferation in BV-2 cells as suggested by cell cycle analysis and cell count. The internalization process of TiONts-APTES into cells by endocytosis vesicles and passive diffusion were proved by transmission electron microscopy (TEM) with and without amiloride, the endocytosis inhibiting agent. In addition, the TiONts-APTES exhibited good biocompatibility on microglial BV-2 cells as revealed by the morphology and viability analysis.

Keywords: Titanate nanotubes; reactive oxygen species; microglial activation; mitochondrial hyperpolarisation; lysosomal integrity; apoptosis

\section{Introduction}

The central nervous system (CNS), comprising the brain and the spinal cord, is a

highly protected organ, owing to the crucial functions it performs. Due to this fact, biomedical interventions in the brain are hard to achieve. Nanoparticles being very small in size can access otherwise protected sites in the body including blood brain barrier and placenta (Kessler, 2011). With the advancement of nanotechnology, many nanoparticles have been suggested as diagnostic and therapeutic modalities for neurobiological applications. Titanate nanotubes (TiONts) are one such particle with a needle-shaped morphology and surface chemistry (with hydroxides) which permit further functionalization (Papa et al., 2015). Since their discovery by Kasuga et al. (1998), TiONts have been studied for a variety of applications (Bavykin and Walsh, 2010). Recently, applications of TiONts have turned to the biomedical field (Kijima, 2010) including dopamine detection (Niu et al., 2008), DNA transfection (Papa et al., 2013), bioimaging (Papa et al., 2011), drug delivery (Loiseau et al., 2017), and cancer cell radiosensitization (Mirjolet et al., 2013, Mirjolet et al., 2017). TiONts have been proposed for glioma therapy (Mirjolet et al., 2013) in addition 
reported that TiONts can be used for the detection of neurotransmitters in the brain (Niu

47 et al., 2008). Though many neurobiological applications have been proposed for

48 TiONts, only a little information is available on the biocompatibility and cellular

49 interaction of these nanoparticles (Rihane et al., 2016, Sallem et al., 2017).

50 One of the main hurdles in the neuro-bio applications of nanoparticles includes

51 nanoparticle-mediated microglial activation. Microglia are major immune cells of the

52 brain which are involved in the scavenger functions and cytokine secretion. The

53 activated microglia can induce oxidative stress in the brain which leads to further

54 complications. In a recent study (Bussy et al., 2015), it was reported that the carbon

55 nanotubes toxicity mainly comes from the microglial activation and oxidative stress.

56 In the present study, TiONts were synthesized by hydrothermal synthesis and

57 functionalized with APTES ((3-aminopropyl) triethoxysilane) for drug delivery

58 applications. APTES functionalization provides TiONts with additional amine functions

59 for drug molecule conjugation, making them better drug carriers. Moreover, APTES-

60 functionalized TiONts exhibit better water dispersion and colloidal stability than bare

61 TiONts. The interaction and biocompatibility of fully characterized TiONts-APTES

62 with microglial cells were studied using microglial cells. BV-2 cell line was selected

63 because it is derived from normal murine microglia and has phenotypic features similar

64 to that of normal microglia (Blasi et al., 1990). The toxicological responses including

65 morphological alteration, reactive oxygen species (ROS) production, cell cycle

66 alteration and cell death were studied using different bio-assays. 


\section{Methodology}

\section{Particle synthesis and characterization}

Titanate nanotubes (TiONts) synthesis:

TiONts were prepared by a classical hydrothermal method in a basic medium

(Papa et al., 2009). $\mathrm{TiO}_{2}$ rutile precursor powder $(1 \mathrm{~g})$ was added to a solution of $\mathrm{NaOH}$

(10 M, $250 \mathrm{~mL}$ ). The mixture was ultrasonicated (30 min, $375 \mathrm{~W}$, Sonics Vibra-Cells)

and then transferred into a Teflon reactor with mechanical stirring and heating at $155^{\circ} \mathrm{C}$ for $36 \mathrm{~h}$. After cooling, the precipitate was centrifuged $(24,000 \times \mathrm{g}$ for $10 \mathrm{~min})$, dialyzed four days $\left(\right.$ Cellu.Sep ${ }^{\circledR}$ tubular membranes of $\left.12-14 \mathrm{kDa}\right)$ and washed by ultrafiltration (regenerated cellulose membranes with a MWCO of $100 \mathrm{kDa}$ ) with deionized water until the conductivity reached $2 \mu \mathrm{S} \mathrm{cm}^{-1}$. Finally, the TiONts were freeze dried.

Functionalization of TiONts with a stabilizing electrostatic agent (APTES):

Silane coupling agents present high reactivity with hydroxyl groups on the surface of metal oxide materials. Therefore, TiONts were modified with APTES (in large excess) via hydrolysis and condensation in a solution of water and ethanol (50:50 $\mathrm{V}: \mathrm{V}$ ) under magnetic stirring for $24 \mathrm{~h}$ to yield TiONts-APTES nanohybrids (Loiseau et $a l ., 2017)$. After the reaction, a part of the solvent was removed with a rotary evaporator $\left(80{ }^{\circ} \mathrm{C} ; 250 \mathrm{mbar}\right)$ then the resulting suspension was ultrafiltered $(100 \mathrm{kDa})$ to eliminate the unreacted APTES. Finally, TiONts-APTES were freeze-dried.

Nanoparticles characterization: 
LaB6 microscope with an acceleration voltage of $200 \mathrm{kV}$ and equipped with a high tilt pole-piece achieving a point-to-point resolution of $0.25 \mathrm{~nm}$ to study nanotube morphology and their agglomeration state. The samples were prepared by dropping a dilute suspension of powders on carbon-coated copper grids. to determine the amount of grafted molecules on the surface of TiONts: water desorption and organic decomposition. The measurements were carried out under air atmosphere $\left(25 \mathrm{~mL} \mathrm{~min}^{-1}\right)$ with a heating rate of $10{ }^{\circ} \mathrm{C} \mathrm{min}^{-1}$ from $50^{\circ} \mathrm{C}$ to $800^{\circ} \mathrm{C}$.

Specific surface area measurements were performed with a Micromeritics

Tristar II apparatus and were calculated with the BET (Brunauer Emmett Teller) method $\left(\mathrm{S}_{\mathrm{BET}}\right)$ from $\mathrm{N}_{2}$ gas adsorption. Samples were first outgassed in situ under a pressure of $20 \mathrm{mTorr}$ at $100^{\circ} \mathrm{C}(16 \mathrm{~h})$ before $\mathrm{N}_{2}$ adsorption/desorption cycles. Zeta potentials ( $\zeta$-potentials) were measured with a Malvern Nano ZS instrument supplied by DTS Nano V7.11 software. The $\mathrm{pH}$ of the suspensions was

102 adjusted from 3 to 11 by adding $\mathrm{HCl}$ or $\mathrm{NaOH}$ solutions. The Smoluchowski equation 103 was used for zetametry measurements. For each measurement, powders were dispersed 104 in $12 \mathrm{~mL}$ of aqueous $\mathrm{NaCl}$ solution (the final concentration of $\mathrm{NaCl}$ is $10^{-2} \mathrm{M}$ ). $\mathrm{pH}$ 105 titrations were performed using aqueous solutions of $\mathrm{HCl}(0.1 \mathrm{M}), \mathrm{NaOH}(0.1 \mathrm{M})$, or $106 \mathrm{NaOH}(0.01 \mathrm{M})$. UV-visible absorbance measurements were carried out using Shimadzu UV1082550 at $600 \mathrm{~nm}$. Stability measurements were made in PBS $0.1 \mathrm{M}$ at $\mathrm{pH}=7.4$ and $\mathrm{T}=$ $10925^{\circ} \mathrm{C}$ (one measurement/5 min) during $120 \mathrm{~min}$ to analyze the colloidal stability.

110 The equipment of Fourier-Transform InfraRed spectroscopy (FT-IR) was a 111 Bruker Vertex 70v using OPUS version 3.1. FT-IR spectra were obtained from 
112 transmission measurements of thin pellets which consist of $2 \mathrm{mg}$ of nanohybrids powder

113 finely ground with dried $\mathrm{KBr}(198 \mathrm{mg})$ before being pressed into a pellet.

114 X-ray Photoelectron Spectroscopy (XPS) analyses were recorded by a PHI 5000

115 Versaprobe apparatus with a monochromatic Al $\mathrm{K}_{\alpha 1} \mathrm{X}$-ray source (energy of $1486.7 \mathrm{eV}$

116 with a $200 \mu \mathrm{m}$ spot size, accelerating voltage of $12 \mathrm{kV}$, and power of $200 \mathrm{~W}$ ). The

117 resolution was $2.0 \mathrm{eV}$ for global spectra and $1.3 \mathrm{eV}$ for windows corresponding to

118 selected lines. The powders were deposited on an indium sheet then pressed.

119 Photoemission peak areas were calculated after subtracting background using a Shirley

120 routine. The titanium $2 \mathrm{p}$ peak $(458.7 \mathrm{eV})$ was used as reference and allowed the

121 correction of charge effects. Gauss (70\%)-Lorentz (30\%) profiles were used and data

122 were analyzed with CasaXPS software for curve fitting and MultiPak software for

123 quantitative analysis.

\section{Cell culture and nanoparticles treatment}

The BV-2 cells were cultured in RPMI medium with $10 \%$ heat inactivated fetal

126 calf serum (FCS) and antibiotic/antimycotic solution as previously described (Nury et

$127 a l ., 2017)$. For the nano-interaction studies, cells were seeded in appropriate seeding

128 density and cultured overnight. The cells were exposed to TiONts-APTES for different

129 times ( 6 and $24 \mathrm{~h}$ ) at concentrations of $1,5,10,20,40$ and $80 \mu \mathrm{g} / \mathrm{mL}$ by diluting the

130 stock solution $(4 \mathrm{mg} / \mathrm{mL})$.

\section{Cytotoxicity and dose response: MTT assay}

132 Cell viability was assessed as a function of mitochondrial activity using MTT (3-

133 (4-,5-dimethylthiazol-2-yl)-2,5-diphenyltetrazolium bromide) assay. Cells were seeded

134 in 12 well plates at an initial seeding density of $5 \times 10^{4}$ and incubated overnight at 
$13537^{\circ} \mathrm{C}, 5 \% \mathrm{CO}_{2}$. After TiONts-APTES exposure, cells were harvested by centrifugation

136 at $200 \times \mathrm{g}$ for $5 \mathrm{~min}$ and then incubated with MTT $(0.05 \mathrm{mg} / \mathrm{mL})$ for $3 \mathrm{~h}$ in the dark. The

137 formazan crystals formed were solubilized using $200 \mu \mathrm{L}$ DMSO and absorbance was

138 read at $540 \mathrm{~nm}$. Final results are obtained by subtracting the absorbance of control wells

139 (without cells) from the absorbance of treated samples in order to avoid nanoparticles

140 interference in MTT results.

\section{Cell morphology: Phase contrast microscopy}

142 Cells were seeded in 12-well plates at an initial seeding density of

$1435 \times 10^{4}$ cells/well. Cells were exposed to TiONts-APTES for $24 \mathrm{~h}$. Cellular morphology

144 was assessed under a phase contrast microscope (Axiovert 40 CFL, Zeiss). Digital

145 images were taken with an Axiocam ICm1 camera (Zeiss).

\section{Particle uptake:}

\section{$147 \quad$ Flow cytometry}

Uptake of TiONts-APTES by microglia was analyzed using flow cytometry

149 following the method of Suzuki et al. (2007). Particle uptake by cells leads to an

150 increase in granularity which is revealed by an increase in the side-scattered light

151 (SSC), while the forward-scattered light (FSC) remains the same. In this experiment,

152 cells were seeded in 6-well plates at an initial density of $1 \times 10^{5}$ and kept overnight for

153 incubation. Cells were then exposed to 5, 20, and $80 \mu \mathrm{g} / \mathrm{mL}$ of TiONts-APTES for $6 \mathrm{~h}$.

154 Cells, harvested by centrifugation, were resuspended in $500 \mu \mathrm{L}$ PBS and analyzed by

155 flow cytometry using a Dako/Partec/GALAXY flow cytometer (Partec, Münster,

156 Germany) equipped with a solid blue laser $(50 \mathrm{~mW})$ and controlled by 'FloMax'

157 software (version 2.4; Partec). 
Transmission electron microscopy (TEM):

162 The cells were seeded at an initial density of $1.175 \times 10^{5} / \mathrm{mL}$ and incubated overnight.

163 Cells were subsequently exposed to $20 \mu \mathrm{g} / \mathrm{mL}$ of TiONts-APTES for $24 \mathrm{~h}$ without and 164 with $100 \mu \mathrm{M}$ amiloride, a macropinocytosis inhibitor (added $1 \mathrm{~h}$ prior to nanoparticles exposure). At the end of treatment, cells were harvested and fixed for $1 \mathrm{~h}$ at $4{ }^{\circ} \mathrm{C}$ in $4 \%$

166 paraformaldehyde and $2.5 \%$ of glutaraldehyde in Sorensen phosphate buffer $(0.1 \mathrm{mM}$,

$167 \mathrm{pH}$ 7.3). After fixation, samples were washed by Sorensen phosphate buffer. The post-

168 fixation treatment was realized with $1 \%$ osmium tetraoxide at room temperature for $1 \mathrm{~h}$.

169 Dehydration and resin impregnation of the samples were performed with a Leica EM

170 AMW automatic microwave tissue processor: dehydration was done by increasing 171 degrees of ethyl alcohol $\left(50^{\circ}, 70^{\circ}, 95^{\circ}, 100^{\circ}\right)$, the substitution of ethanol by resin was 172 progressively done by three absolute ethanol/Embed-812 resin mixtures $(3 / 4,1 / 2,1 / 3$ 173 ethanol), followed by two impregnations in pure Embed-812 resin. The polymerization 174 of samples was performed with a mixture Embed-812/3\% benzyldimethylamine 175 (BDMA, polymerisation catalyst) in gelatin capsule maintained for $48 \mathrm{~h}$ at $60{ }^{\circ} \mathrm{C}$.

176 Blocks were cut on a Reichert ultramicrotome and slices (thickness of $70 \mathrm{~nm}$ ) were 177 deposited on copper and palladium grid. After drying, grids were contrasted with uranyl 178 acetate and lead citrate. TEM observations of cells were realized on a HITACHI H1797500 operating at $80 \mathrm{kV}$. For each test carried out, one grid per sample was observed, 180 which corresponds to a total of 30 to 50 cells. The photos presented are representative 181 of the cells observed by samples. 


\section{Reactive oxygen species analysis}

183 Superoxide radicals: DHE probe

184 Superoxide anions production in presence of TiONts-APTES was measured

185 using a cell permeable molecule, dihydroethidium (DHE; Life Technologies, St Aubin,

186 France). DHE, mainly upon reaction with superoxide anions $\left(\mathrm{O}_{2}^{\bullet}\right)$, forms a red

187 fluorescent product, 2-hydroxyethidium, which intercalates with DNA. The cells were

188 seeded in 12-well plates at a density of $5 \times 10^{4}$ cells/well and kept overnight in the $\mathrm{CO}_{2}$

189 incubator. After TiONts-APTES exposure, the cells were harvested by centrifugation.

190 The pellets were resuspended in $1 \mathrm{~mL}$ PBS containing 1.6 mM DHE and incubated for

$19115 \mathrm{~min}$ at $37^{\circ} \mathrm{C}$. The cells were analyzed by Dako/Partec/GALAXY flow cytometer

192 (Partec) through a 590/10 nm band pass filter.

193 Peroxide radicals: DHR123 probe

194 Hydrogen peroxide production in the presence of TiONts-APTES was estimated

195 using dihydrorhodamine 123 (DHR123, Sigma-Aldrich, USA). DHR 123 is an

196 uncharged and non-fluorescent molecule that can passively diffuse across plasma

197 membranes where it is oxidized to cationic rhodamine 123 by hydrogen peroxide

$198\left(\mathrm{H}_{2} \mathrm{O}_{2}\right)$ to give green fluorescence. The cells were seeded on 24 well plates at an initial

199 density of $2 \times 10^{4}$ cells/well and exposed to 5, 20, 40 and $80 \mu \mathrm{g} / \mathrm{mL}$ of TiONts-APTES

200 for 6 and $24 \mathrm{~h}$. The cells were harvested after centrifugation and resuspended in $1 \mathrm{~mL}$

201 PBS. 2mM DHR123 were added to each tube at a final concentration of $6 \mu \mathrm{M}$ and

202 incubated for $15 \mathrm{~min}$ at $37^{\circ} \mathrm{C}$. Fluorescence were measured using

203 Dako/Partec/GALAXY flow cytometer (Partec) with a 520/20 nm band pass filter. 
Alteration in transmembrane mitochondrial potential $(\Delta \Psi \mathrm{m})$ was analyzed using a fluorescent probe: 3,3'-dihexyloxacarbocyanine iodide ( DiOC $_{6}(3)$ (Life Technologies,

207 Molecular Probes). DiOC $_{6}(3)$ is a cell-permeant, green-fluorescent, lipophilic dye, 208 which is selective for the mitochondria of live cells when used at a nanomolar 209 concentration. $\operatorname{DiOC}_{6}(3)$ allows measuring $\Delta \Psi \mathrm{m}$. The cells were seeded at an initial 210 density of $2 \times 10^{4}$ cells/well of 24 well plates and incubated overnight. They were exposed to TiONts-APTES of concentration 1, 10, 20, 40 and $80 \mu \mathrm{g} / \mathrm{mL}$ for $6 \mathrm{~h}$ and $24 \mathrm{~h}$. Cells incubated with $4 \%$ paraformaldehyde (in DPBS for $10 \mathrm{~min}$ at $37^{\circ} \mathrm{C}$ ) were used as positive control. The cells washed in PBS were incubated with $\mathrm{DIOC}_{6}(3)$ $\left(0.1 \mu \mathrm{M}\right.$ in PBS) for $15 \mathrm{~min}$ at $37^{\circ} \mathrm{C}$. The flow cytometry analysis was done using the DAKO/GALAXY flow cytometer (Partec, Germany) with a 520/20 nm band pass filter.

\section{Lysosomal membrane integrity: Acridine orange staining}

Lysosomal destabilization in presence of nanoparticles was analyzed using acridine orange (AO). $\mathrm{AO}$ is a lipophilic, cationic and metachromatic fluorochrome capable of permeating cells and organelle membrane structure. Under a blue light excitation, the dye differentially stains cytoplasm and acid vesicles (Pierzyńska-Mach et $a l ., 2014)$. In normal cells, the dye gets protonated inside acidic vesicles and emits orange fluorescence whereas the cytoplasm remains green in color. When the cells have altered lysosomes, leading to an alteration of the proton pump, the resulting alkalinisation of the lysosomes is associated with a green/yellow fluorescence of these vesicles. The cells, seeded at an initial density of $2 \times 10^{4}$ cells/well of 24 well plates, were exposed to TiONts-APTES $(5,20,40$, and $80 \mu \mathrm{g} / \mathrm{mL})$ for $6 \mathrm{~h}$ and $24 \mathrm{~h}$. The cells,

227 harvested by direct pipetting, were washed with PBS and incubated in $1 \mathrm{~mL}$ AO 
solution $\left(2 \mu \mathrm{g} / \mathrm{mL}\right.$ in PBS) for $15 \mathrm{~min}$ at $37^{\circ} \mathrm{C}$. The analysis was carried out using a

229 Dako/Partec/ GALAXY flow cytometer (Partec) with a 590/10 nm band pass filter.

Plasma membrane integrity: Propidium Iodide (PI) staining

231

The plasma membrane integrity on TiONts-APTES exposure was analyzed by

Propidium Iodide (PI) staining. The principle underlying the PI staining is dye exclusion

by living cells (Lizard et al., 1995). Cells seeded at an initial density of $2 \times 10^{4}$

234 cells/well of 24 well plates were exposed to TiONts-APTES $(5,20,40$, and $80 \mu \mathrm{g} / \mathrm{mL})$

235 for 6 and $24 \mathrm{~h}$. Harvested cells were washed and stained with PI $(1 \mu \mathrm{g} / \mathrm{mL})$ for $15 \mathrm{~min}$

236 at $37^{\circ} \mathrm{C}$. The flow cytometry analysis was done using Dako/Partec/GALAXY flow 237 cytometer (Partec) with a $630 \mathrm{~nm}$ long pass filter.

Poly(ADP-ribose) polymerase (PARP) cleavage assay

The cells were seeded at an initial density of $2 \times 10^{4}$ cells/well of 24 well plates

and incubated overnight. The cells were exposed to $20 \mu \mathrm{g} / \mathrm{mL}$ and $80 \mu \mathrm{g} / \mathrm{mL}$ of TiONtsAPTES for $24 \mathrm{~h}$. Untreated cells were used as control. After treatment cells were harvested and centrifuged at $200 \times \mathrm{g}, 4^{\circ} \mathrm{C}$ for $5 \mathrm{~min}$.

The cell pellets were transferred to fresh tubes and washed with $1 \mathrm{~mL}$ cold PBS.

245 After discarding supernatant, the pellets were incubated with $80 \mu \mathrm{L}$ of RIPA buffer

246 containing $1 \times$ anti-protease for $30 \mathrm{~min}$ on ice. The cell suspension was centrifuged at

$24712,000 \times \mathrm{g}$ for $20 \mathrm{~min}$ at $4^{\circ} \mathrm{C}$. Supernatant was collected in a fresh tube (this solution can

248 be stored at $-20^{\circ} \mathrm{C}$ for weeks and thawed at room temperature) and the pellet was

249 discarded. The concentration of protein solution was measured by BCA (Bicinchoninic 
250 acid assay) with $2 \%$ copper sulfate solution. $25 \mu \mathrm{L}$ of BSA was used as protein standard

251 and concentration was calculated from the standard graph obtained.

252

254

255

256

257

258

259

260

261

262

263

264

265

266

267

\section{Loading and running gel}

The isolated protein was loaded in $8 \%$ polyacrylamide gel at a concentration of $70 \mu \mathrm{g} / \mathrm{well}$. Electrophoresis was carried out for $2 \mathrm{~h}(30 \mathrm{~min}$ at $70 \mathrm{~V}$ followed by $1.5 \mathrm{~h}$ at $120 \mathrm{~V})$.

\section{Gel to membrane transfer of protein}

The polyvinylidene difluoride (PVDF) membrane was activated with methanol for 1 min and rinsed with transfer buffer. Gel stack was prepared by sandwiching the gel and PVDF membrane between filter papers and sponges and keeping them in transfer buffer for $1 \mathrm{~h}$.

\section{Antibody revelation by chemiluminescence}

The protein attached membrane was blocked using 5\% milk solution for $1 \mathrm{~h}$ at room temperature and washed 3 times with PBST (PBS and Tween 20, 0.1\%) for 5 min each. It was transferred into a solution containing primary antibody $(1: 1,000)$ and incubated overnight at $4^{\circ} \mathrm{C}$. Antibody for actin $(1: 10,000)$ was used as a standard. The solution was washed 5 times with PBST (5 min each). The membrane was then incubated with secondary antibody (in $1 \%$ milk) for $1 \mathrm{~h}$ at $25^{\circ} \mathrm{C}$ and covered in a transparent plastic wrap after removing excess reagent. The image was acquired by chemiluminescence method. 
The changes in cell cycle patterns were analyzed by staining with propidium iodide (PI) (Marel et al., 2008). In brief, the cells were seeded at an initial density of $2 \times 10^{4}$ cells/well on 24 well plates and exposed to TiONts-APTES (5, 20, 40, and $80 \mu \mathrm{g} / \mathrm{mL}$ ) for $24 \mathrm{~h}$. Cells, harvested by direct pipetting, were washed with PBS. The pellets were fixed using $1 \mathrm{~mL}$ cold $80 \%$ ethanol (kept at $-20^{\circ} \mathrm{C}$ ), by vortexing, to avoid cell aggregation and kept at $-20^{\circ} \mathrm{C}$ for at least $2 \mathrm{~h}$ (cells can be kept in this condition for few days.). The cells were washed (350xg for $5 \mathrm{~min}$ ) and resuspended in $300 \mu \mathrm{L}$ PBS containing $80 \mu \mathrm{g} / \mathrm{mL}$ PI and $200 \mu \mathrm{g} / \mathrm{mL}$ RNase. After $1 \mathrm{~h}$ incubation at $37^{\circ} \mathrm{C}$, the solution was made up to $1 \mathrm{~mL}$ by adding $700 \mu \mathrm{L}$ PBS and analyzed using flow cytometry on a Dako/Partec/GALAXY flow cytometer (Partec) with a 630nm long pass 281 filter.

\section{Statistical analysis}

All the experiments were done in triplicates and the values were expressed as mean \pm SD. Statistical comparison between the control and experimental values were

286 done using one-way ANOVA test. In result, analyses with $p<0.05$ were considered as statistically significant.

\section{Results}

Nanotubes synthesis, functionalization, and characterizations TEM images were used to highlight the synthesis of TiONts after the hydrothermal treatment. They present a spiral-shaped morphology, with internal cavity 292 (Figure 1a,b) and a high specific surface area $\left(\mathrm{S}_{\mathrm{BET}}=174 \pm 1 \mathrm{~m}^{2} \mathrm{~g}^{-1}\right)$. They are $(10 \pm 1)$ 
$\mathrm{nm}$ in outer diameter and $(170 \pm 50) \mathrm{nm}$ in length.

The functionalization of TiONts with APTES (Figure 1e,f) seems to reduce nanoparticles agglomeration and improve their dispersion in comparison to bare TiONts

(Figure 1c,d). The grafting ratio of APTES on the surface of TiONts was determined by

TGA (Figure 2). The amount of hydroxyl groups on the surface of bare TiONts was calculated based on water weight loss from TGA curve. Indeed, the release of one molecule of chemisorbed water involves the condensation of two hydroxyl groups. As the weight loss below $175^{\circ} \mathrm{C}$ is due to physisorbed water (Sabzi et al., 2009), only the weight loss related to chemisorbed water between $175{ }^{\circ} \mathrm{C}$ and $800{ }^{\circ} \mathrm{C}$ is taken into account for hydroxyl and grafting ratio estimation. Consequently, a greater weight loss is obtained after APTES grafting (Figure 2 and Table 1). The results show a hydroxyl

304 density of about $(10.6 \pm 1.5)$ OH.nm ${ }^{-2}$ and APTES grafting ratio of $(7.3 \pm$ 0.5) APTES.nm ${ }^{-2}$. It should be noted that the specific surface area of TiONts decreases after their functionalization with APTES $\left(S_{\mathrm{BET}}=147 \pm 2 \mathrm{~m}^{2} \mathrm{~g}^{-1}\right)$. APTES may form an envelope all around TiONts and hinder, at least partially, access to internal cavities. $\zeta$-potential measurements of TiONts-APTES indicated an isoelectric point (IEP) at $\mathrm{pH} 8.5$ (Figure 3). This value is greater than that of bare TiONts (IEP at $\mathrm{pH} 3.3$ ) due to the presence of amine functions (Paris et al., 2015). Moreover, an inversion in

$311 \zeta$-potential sign is also observed at physiological $\mathrm{pH}$, where it is positive $c a .+10 \mathrm{mV}$

312 for APTES-functionalized TiONts and largely negative (ca. $-25 \mathrm{mV})$ for bare TiONts. X-ray Photoelectron Spectroscopy (XPS) analyses are realized to evaluate the

314 chemical composition of the surface of TiONts-APTES. Besides to the chemical 315 elements that are present in bare TiONts, some additional specific elements, such as 316 nitrogen and silicon, are also found in TiONts-APTES (Table 2), thus proving the 317 presence of APTES at the surface of nanotubes. 
319 onto the surface of TiONts (Figure 4). APTES characteristic bands are located at $1000 \mathrm{~cm}^{-1}\left(v\right.$ Si-O-Si), $1100-1200 \mathrm{~cm}^{-1}(v \mathrm{C}-\mathrm{N})$ and $3250 \mathrm{~cm}^{-1}\left(v \mathrm{NH}_{2}\right)$.

\section{Cytotoxicity and dose response: MTT assay}

322

323

324

325

326

After $6 \mathrm{~h}$, the exposure to TiONts-APTES does not markedly alter cells viability, which is evaluated with the MTT assay by measuring the activity of succinate dehydrogenase, except for $80 \mu \mathrm{g} / \mathrm{mL}$ treated wells. A statistically significant increase in absorbance (\% control) is observed for $80 \mu \mathrm{g} / \mathrm{mL}$ treated samples at $6 \mathrm{~h}$ of exposure which subsided by $24 \mathrm{~h}$. The absorbance is significantly reduced in $20(93.80 \pm 5.84 \%)$, $40(90.12 \pm 4.17 \%)$ and $80(84.24 \pm 4.12 \%) \mu \mathrm{g} / \mathrm{mL}$ TiONts-APTES treated wells at $24 \mathrm{~h}$ of incubation (Figure 5a).

\section{Cell morphology}

The cellular morphology in presence of TiONts-APTES is evaluated using a phase contrast microscopy. The treated cells do not show any alteration in their morphology like membrane rupture, swelling, blebbing and/or cytoplasmic disintegration which are morphological features usually associated to cytotoxic effects. The cells size and morphology are similar to those of the negative control cells (Figure $6 a)$.

\section{Particle uptake}

TiONts-APTES uptake by BV-2 cells is analyzed from the SSC changes in flow cytometry. As shown in Figure $6 \mathrm{~b}$ the TiONts-APTES exposed cells exhibit a dosedependent increase in SSC (5 $\mu \mathrm{g} / \mathrm{mL}: 5.04 \%$ and $80 \mu \mathrm{g} / \mathrm{mL}: 35 \%)$ compared to negative 
$(2.56 \%)$ and positive controls (12.5\%) suggesting an internalization and/or an interaction of nanoparticles with the plasma membrane.

To define whether the nanoparticles were internalized and to determine by

343 which mechanism - the passive (diffusion through the plasma membrane) or the active

344 one (endocytose) - they can accumulate inside the cells, the nanoparticles uptake was

345 studied by TEM. Cells are incubated with TiONts-APTES $(20 \mu \mathrm{g} / \mathrm{mL}, 24 \mathrm{~h})$, without 346 and with amiloride $(100 \mu \mathrm{M})$, an endocytosis inhibiting molecule introduced in the

347 culture medium $1 \mathrm{~h}$ before nanoparticles (Figure 7). In TiONts-APTES-treated cells, the

348 presence of nanoparticles was revealed in large vesicles (average diameters of the 349 vesicles: $0.85 \pm 0.32 \mu \mathrm{m}$ ) in all the observed cells (Figure 7b,b1,b2). However, when 350 BV-2 cells were cultured with amiloride, only few cells with internalized nanoparticles 351 (around $10 \%$ ) were found: this data supports TiONts-APTES internalization mainly by endocytosis (Figure 7c,c1). In these conditions, the interactions of nanoparticles with the plasma membrane are however observed, and their diffusion through the plasma membrane are detected (Figure $7 \mathrm{c} 2, \mathrm{c} 3, \mathrm{c} 4$ ). It is noteworthy that the size of the endocytic vesicles in amiloride-treated cells $(0.50 \pm 0.16 \mu \mathrm{m})$ are smaller than those in

356 cells treated with nanoparticles only. Altogether, these data support that nanoparticles enter in cells mainly by endocytosis and show that a passive diffusion does exist. In the latter case, more individualized TiONts are observed into the cytoplasm and some of them are closer to nucleus.

On the other hand, a change in the mitochondrial behavior is observed in cells

361 uptaking nanoparticles. Indeed, in the control cells, mitochondria are usually situated 362 near to nucleus, in the majority of cells, however, in contact with TiONts-APTES, many 363 mitochondria are located near the cellular membrane (Figure c2) or near the endocytic 364 vesicles containing nanoparticles (Figure d,e). In addition, bigger mitochondria are 
365 observed in nanoparticles-treated cells $(0.94 \pm 0.57 \mu \mathrm{m})$ compared to control $(0.64 \pm 0.29$

$366 \mu \mathrm{m})$. This change in mitochondrial size could be induced by the presence of TiONts-

367 APTES nanoparticles and may affect the mitochondrial function.

\section{ROS overproduction}

Superoxide radicals

370

Superoxide anion production in the presence of TiONts-APTES is studied using

371 the probe DHE. The cells exhibited a concentration dependent increase in DHE

372 fluorescence at $6 \mathrm{~h}$ of incubation. However, at $24 \mathrm{~h}$ of treatment the particular trend was

373 not observed in the treated wells, where the percentage of cells exhibiting DHE

374 fluorescence declined. No concentration dependent increase in DHE positive cells were 375 observed at $24 \mathrm{~h}$ except for $80 \mu \mathrm{g} / \mathrm{mL}$ TiONts-APTES (Figure $8 \mathrm{a}$ ).

376 Hydrogen Peroxide

Hydrogen peroxide production in the presence of TiONts-APTES is studied

378 using the probe DHR 123 which is a cellular indicator of peroxides and peroxynitrite 379 production. The results obtained shows little increase in the percentage of cells 380 overproducing peroxide radicals' at $6 \mathrm{~h}$ except for the highest concentration of TiONts-

381 APTES $(80 \mu \mathrm{g} / \mathrm{mL}$ ) (Figure 8a). Cells treated with $80 \mu \mathrm{g} / \mathrm{mL}$ showed statistically 382 significant increase in peroxide radical production at $6 \mathrm{~h}$. On the other hand, TiONts383 APTES exposure at $24 \mathrm{~h}$ showed a concentration-dependent and statistically significant 384 increase in peroxides production (Figure $8 b$ ). 
A possible $\Delta \Psi \mathrm{m}$ change in response to TiONts-APTES is evaluated using

387 fluorescent probe $\mathrm{DiOC}_{6}(3)$. Cells exhibit an initial mitochondrial hyperpolarization

388 after $6 \mathrm{~h}$ of exposure, as revealed by the increase in the green intensity of $\mathrm{DiOC}_{6}(3)$.

389 7-ketocholesterol (7-kc)-treated cells (positive control) also exhibits similar response.

390 However, after $24 \mathrm{~h}$, the $\Delta \Psi \mathrm{m}$ in treated cells reverts to normal state and becomes

391 similar to controls (Figure 9).

\section{Lysosomal membrane integrity}

Lysosomal membrane integrity in the presence of TiONts-APTES is analyzed by staining with acridine orange (AO). Flow cytometry analysis of AO stained cells does not indicate any signs of lysosomal membrane permeabilization (LMP) in TiONtsAPTES-treated cells. AO signals increase in the treated cells for both 6 and $24 \mathrm{~h}$ suggesting the absence of TiONts-APTES mediated LMP in BV-2 cells (Figure 10).

\section{Plasma membrane integrity}

Plasma membrane integrity in the presence of TiONts-APTES is analyzed using

400 PI staining. Flow cytometry analysis of the PI stained cells indicates no significant 401 increase in the PI positive cells for $24 \mathrm{~h}$ with respect to control. As shown in Figure 11, 402 cells treated with $80 \mu \mathrm{g} / \mathrm{mL}$ of TiONts-APTES show only $4.5 \%$ PI positive cells 403 compared to $65.5 \%$ PI positive cells in 7-kc treated wells (positive control).

\section{Mechanism of cell death}


407 via apoptosis as evidenced by PARP cleavage assay. A light band of cleaved PARP

408 could be visible in both 20 and $80 \mu \mathrm{g} / \mathrm{mL}$ of TiONts-APTES treated cells at $24 \mathrm{~h}$ (Figure 409 12).

\section{$410 \quad$ Cell cycle analysis}

TiONts-APTES mediated cell cycle changes are evaluated by staining the cells

412 with PI. The flow cytometry analysis of PI-stained cells indicates no alteration in cell

413 cycle pattern in the presence of TiONts-APTES. Moreover, SubG1 population

414 indicative of apoptotic cells (Ormerod et al., 1992) are not visible in TiONts-APTES

415 treated cells for $24 \mathrm{~h}$ of incubation (Figure 13).

\section{Discussion}

TiONts have been proposed for a variety of biomedical applications including

418 drug delivery, bioimaging, cancer therapy, biosensing and disease diagnosis (Papa et al., 2011, Mirjolet et al., 2013, Papa et al., 2013, Boudon et al., 2014, Loiseau et al., 2017, Mirjolet et al., 2017). TiONts are ideal candidates for neuro-bio applications

421 because of their low toxicity. In the present study, TiONts-APTES nanoparticles, synthesized for drug delivery applications across BBB, are evaluated for their toxicity using microglial cells line BV-2.

APTES grafting onto TiONts surface is confirmed by several chemical characterization techniques such as zeta potential measurement, XPS and IR 426 spectroscopy. Indeed, the increase in the zeta potential value and the isoelectric point 427 after APTES grafting prove the presence of positively charged functional group on the surface (amine groups). The increase in carbon percentage and the appearance of new chemical elements such as nitrogen and silicon, observed by XPS analysis, confirm the 
430 APTES grafting. Moreover, IR spectroscopy shows the characteristic vibration bands of

431 APTES in TiONts-APTES spectrum. The grafting density of this molecule is estimated

432 by thermogravimetric analysis to $(7.3 \pm 0.5)$ APTES $/ \mathrm{nm}^{2}$ of nanotubes, based on the

433 difference in the weight losses between bare and grafted TiONts.

434 Cytotoxicity and dose response are studied in terms of mitochondrial activity by

435 MTT assay. The mitochondrion is a highly sensitive organelle and hence early stage

436 changes in the cellular health are reflected in mitochondrial activity. Dose-dependent

437 alteration in mitochondrial activity after cells exposure to TiONts has been reported in

438 some studies (Iavicoli et al., 2011). Despite the change in mitochondria location and

439 morphology observed in the present study through TEM images, no marked reduction in

440 mitochondrial activity is observed after TiONts-APTES exposure. The statistically

441 significant reduction observed in the mitochondrial activities are not beyond $30 \%$ to be

442 called as cytotoxic according to the ISO 10993-5 guidelines for the in vitro cytotoxicity

443 evaluation of medical devices. It is reported that $\mathrm{TiO}_{2}$ nanoparticles interfere with MTT

444 to give false positive results (Lupu and Popescu, 2013). In the present study, absorbance

445 values of controls (without cells) are subtracted from the MTT results to rule out 446 nanoparticles interference.

447 MTT results are just an indicator of cell metabolic state. Changes in MTT 448 signals can be due to a cytotoxic effect, a cytostatic effect (Riss et al., 2016) or to a loss 449 of cells during the assay procedure. Therefore it is important to correlate the MTT 450 results with cellular morphology and total cell count (Quent et al., 2010). For this 451 reason, Trypan blue exclusion assay is carried out to count the cells (data not shown 452 here). In the present study, even high concentrations of TiONts-APTES does not elicit 453 any morphological alteration or reduction in cell size or density after $24 \mathrm{~h}$ of exposure.

454 It can be concluded from the obtained results, that the decrease in mitochondrial 
activity, observed in MTT assay, cannot be due to the cytotoxic effect of TiONts-

456 APTES. It is reported that $\mathrm{TiO}_{2}$ nanoparticles induce size reduction and morphological 457 alterations in cells (Saquib et al., 2012). However, it is shown in the current result that TiONts-APTES do not elicit any morphological alterations in BV-2 cells. Cellular uptake of nanoparticles is an important event in bio-nano interaction.

460 Drug delivery applications require nanoparticles internalization. Moreover, the low 461 toxicity, indicated in nanotoxicological studies, can be due to the failure of cells to 462 internalize particles. In the present study cellular internalization of TiONts-APTES is 463 proved by SSC granularity measurements and TEM observations. On the one hand, the 464 dose dependent increase in SSC indicates nanohybrids uptake by BV-2 cells. Indeed, 465 the results of the current study are in corroboration with those of Chen et al. (2010) 466 where cellular internalization of $\mathrm{TiO}_{2}$ nanorods was shown. As the increase in SSC may 467 be also the result of apoptotic vesicles increase, the cells are exposed to a cytotoxic agent, 7-kc, to differentiate if the observed increase in granularity is due to TiONts469 APTES uptake or apoptosis. The SSC changes in 7-kc treated cells are not as 470 pronounced as those observed for TiONts-APTES which confirms the latter's uptake by 471 BV-2 cells. On the other hand, TEM images confirm the internalization of TiONts472 APTES and show two uptake processes; the first and main one is endocytosis process 473 which is a dynamic internalization way, and during which the nanoparticles uptake is 474 carried out by endocytic vesicles. The second and less probable process is the 475 internalization of individualized nanotubes by passive diffusion through the cellular 476 membrane. The latter mechanism is observed when the endocytosis phenomenon is 477 inhibited with amiloride. This molecule is also used by (Huerta-Garcia et al.,2015) to 478 illustrate the $\mathrm{TiO}_{2}$ nanoparticles internalization by macropinocytosis for glial cells. It 479 has been chosen because macropinocytosis is the main internalization pathway of 
480 "large" objects (Benmerah and Lamaze, 2002). Moreover, this endocytic route has been previously emphasized for TiONts internalization in cardiomyocytes (Papa et al., 2013).

482 Since the nanotubes elaborated in this study are agglomerated with sizes higher than several hundreds of nanometers (see Figure 7), macropinocytosis seems to be relevant. Moreover, the presence of nanoparticles in contact with microglial cells may induce a change in mitochondria location and size which can be explained by changes in mitochondrial activity, however no change in cell size or morphology is observed. membrane permeabilization (LMP) is one of the factors contributing to metal oxide nanoparticles toxicity (Sabella et al., 2014). In this work TiONts-APTES nanoparticles do not induce LMP in BV-2 cells as it is indicated by the unaltered intensity of AO signal.

ROS production is an important factor contributing to nanoparticle mediated toxicity. In the present study, BV-2 cells exhibit dose dependent increase in superoxide anion production after $6 \mathrm{~h}$ which get normalized by $24 \mathrm{~h}$. On the other hand, the level of 495 peroxide radicals remains similar across all experiment groups for $6 \mathrm{~h}$ which get 496 elevated in a dose dependent manner for $24 \mathrm{~h}$. This time-dependent increase in peroxide radicals may be due to the delayed induction of superoxide dismutase which carries out the enzymatic conversion of superoxide radicals. Microglia in response to toxic signals may undergo an oxidative burst. This can be monitored by the immediate rise in

500 superoxide radicals which ultimately get converted into peroxide radicals (Long et al., 501 2006). The results obtained in this work are in concordance with the aforementioned 502 findings.

BV-2 cells exposed to TiONts-APTES exhibit an increase in $\triangle \Psi \mathrm{m} 6 \mathrm{~h}$ after 504 incubation. Hyperpolarization is an early and reversible event in immune cell activation 
and apoptosis (Perl et al., 2004). Oxidative burst and mitochondrial hyperpolarization

506 point to the chance of TiONts-APTES mediated microglial activation in cells.

507 Microglial activation is characterized by increased cell proliferation, altered

508 morphology and increase in the cell size (Block and Hong, 2007). To examine

509 microglial activation potential of TiONts-APTES, cell cycle analysis is carried out. No

510 sign of cell cycle alterations is observed in TiONts-APTES exposed cells. Normal ' $\mathrm{S}$ '

511 phase in treated cells confirms the absence of increased DNA synthesis in BV-2 cells.

512 On the other hand, cytotoxic agent 7-kc cholesterol induces a significant reduction in $\mathrm{S}$

513 and G2-M phases with a corresponding increase in Sub G1 (apoptotic) population. The

514 morphological analysis further supports these findings where no change in morphology,

515 cell size or cell density is observed in BV-2 cells exposed to TiONts-APTES suggesting

516 their low cytotoxicity.

$517 \quad$ Nanoparticle-mediated cell death can occur via the two main types of cell death:

518 apoptosis and necrosis (Hirsch et al., 1998). To study the mechanism of TiONts-APTES

519 mediated cell death, the PARP cleavage assay is carried out. PARP cleavage is a marker

520 for apoptotic mode of cell death and is mediated by suicidal proteases like caspases and

521 cathepsin (Boya and Kroemer, 2008). TiONts-APTES exposure induced PARP

522 cleavage in BV-2 cells. Studies show that lysosomal proteases are probably involved in

523 nanoparticles toxicity (Sruthi and Mohanan, 2016). To evaluate whether the PARP

524 cleavage is influenced by the lysosomal proteases (cathepsin), cells are pre-treated with

525 a cathepsin inhibitor Z-FA-FMK. In contrary to the expectation, the cathepsin inhibitor,

526 which also induces PARP fragmentation, does not attenuate PARP cleavage in BV-2

527 cells. The result of the PARP cleavage suggests a potential activation of an apoptotic

528 mode of cell death in TiONts-APTES exposed BV-2 cells. 
530 of cell death. The loss of plasma membrane integrity occurs in the late phase of 531 apoptosis. Cells at the early stage of apoptosis possess intact membrane. Absence of PI 532 positive cells in the population after $24 \mathrm{~h}$ of TiONts-APTES incubation further 533 supported TiONts-APTES mediated apoptosis in BV-2 cells. Moreover, it suggests that 534 BV-2 cells are probably at their early stage of apoptosis at $24 \mathrm{~h}$ of treatment.

\section{Conclusion}

Safety and toxicity are major concerns when it comes to biomedical applications

537 of nanoparticles. In the present study, bio-interaction of APTES-functionalized TiONts 538 were carried out using BV-2 microglial cells. Despite the changes in mitochondrial activity and ROS production, no morphological variation or plasma membrane

540 permeability alteration was observed in cells exposed to TiONts-APTES. These results

541 were confirmed by TEM images that showed a normal cellular morphology after

542 TiONts-APTES uptake and changes in mitochondria location and size. The particles

543 induced an initial increase in transmembrane mitochondrial potential $(\Delta \Psi \mathrm{m})$ which

544 reverted to normal state by $24 \mathrm{~h}$. TiONts-APTES do not interfere with lysosomal

545 membrane integrity or cell cycle. Caspase-dependent apoptosis probably mediates the

546 toxicity. The time- and dose-dependent toxicity is obvious only at the highest

547 concentration used $(80 \mu \mathrm{g} / \mathrm{mL})$. It is shown through TEM images that the main process

548 of nanoparticles internalization in BV-2 cells is endocytosis. These cells do not show

549 any sign of activation which is a major hurdle in drug delivery applications across brain.

550 This study proves that APTES-functionalized TiONts are a potential candidate for drug 551 delivery applications across the brain. 


\section{Acknowledgments}

553 The authors thank the Director and the Head, Bio Medical Technology Wing, Sree

554 Chitra Tirunal Institute for Medical Sciences and Technology, Thiruvananthapuram for

555 providing the infrastructure. Sruthi S thanks, University Grants Commission, New

556 Delhi and Indo-French Centre for the Promotion of Advanced Research, New Delhi for

557 the Junior Research Fellowship and the Raman-Charpak Fellowship. The authors are

558 also grateful to Thomas Nury for his expertise in flow cytometry and western blot

559 analysis, to Dr. Olivier Heintz for XPS measurements and to Dr. Rémi Chassagnon for

560 TEM observations. This work was also possible with help from CellImaP / Dimacell

561 core facility of the University of Burgundy, especially Amandine Bataille for electron

562 microscopy. The core facility is supported by the following institutions: Conseil

563 Régional Bourgogne Franche-Comté through the "Plan d'Actions Régional pour

564 l'Innovation (PARI)" and the European Union through the PO FEDER-FSE Bourgogne

$5652014 / 2020$ programs.

567 Declaration of interest

The authors report no conflicts of interest.

\section{References}

570 Bavykin, D.V., Walsh, F.C., 2010. Titanate and titania nanotubes: synthesis, properties 571 and applications, in: Cambridge, UK, Royal Society of Chemisty, 154 pp.

572 Benmerah, A., Lamaze, C., 2002. Multiple endocytic pathways in mammalian cells. Med. Sci., 18, 1126-1136. 
Blasi, E., Barluzzi, R., Bocchini, V., Mazzolla, R., Bistoni, F., 1990. Immortalization of murine microglial cells by a v-raf/v-myc carrying retrovirus. J. Neuroimmunol., $27,229-237$.

Block, M., Hong, J.S., 2007. Chronic microglial activation and progressive dopaminergic neurotoxicity. Biochem. Soc. Trans., 35, 1127-1132.

Boudon, J., Papa, A., Paris, J., Millot, N., 2014. Titanate nanotubes as a versatile platform for nanomedicine, in: Nanomedicine, Seifalian, A., De Mel, A., Kalaskar, D.M., One Central Press (OCP), pp.403-428.

Boya, P., Kroemer, G., 2008. Lysosomal membrane permeabilization in cell death. Oncog., 27, 6434-6451.

Bussy, C., Al-Jamal, K.T., Boczkowski, J., Lanone, S., Prato, M., Bianco, A., Kostarelos, K., 2015. Microglia determine brain region-specific neurotoxic responses to chemically functionalized carbon nanotubes. ACS nano, 9, 78157830.

Chen, J., Zhou, H., Santulli, A.C., Wong, S.S., 2010. Evaluating cytotoxicity and cellular uptake from the presence of variously processed $\mathrm{TiO}_{2}$ nanostructured morphologies. Chem. Res. Toxicol., 23, 871-879.

Hirsch, T., Susin, S., Marzo, I., Marchetti, P., Zamzami, N., Kroemer, G., 1998. Mitochondrial permeability transition in apoptosis and necrosis. Cell Biol. Toxicol., 14, 141-145.

Huerta-García, E., Márquez-Ramírez, S.G., del Pilar Ramos-Godinez, M., LópezSaavedra, A., Herrera, L.A., Parra, A., Alfaro-Moreno, E., Gómez, E.O., LópezMarure, R., 2015. Internalization of titanium dioxide nanoparticles by glial cells is given at short times and is mainly mediated by actin reorganization-dependent endocytosis. Neurotoxicol., 51, 27-37. 
599 Iavicoli, I., Leso, V., Fontana, L., Bergamaschi, A., 2011. Toxicological effects of 600 titanium dioxide nanoparticles: a review of in vitro mammalian studies. Eur. 601 Rev. Med. Pharmacol. Sci., 15, 481-508.

602 Kasuga, T., Hiramatsu, M., Hoson, A., Sekino, T., Niihara, K., 1998. Formation of 603 titanium oxide nanotube. Langmuir, 14, 3160-3163.

604 Kessler, R., 2011. Engineered nanoparticles in consumer products: understanding a new 605 ingredient. Environ. Health Perspect., 119, A120-A125.

606 Kijima, T., 2010. Inorganic and Metallic Nanotubular Materials: Recent Technologies 607 and Applications, in: Kijima, T. (Eds), Springer-Verlag Berlin Heidelberg.

Lizard, G., Fournel, S., Genestier, L., Dhedin, N., Chaput, C., Flacher, M., Mutin, M., Panaye, G., Revillard, J.P., 1995. Kinetics of plasma membrane and mitochondrial alterations in cells undergoing apoptosis. Cytometry A, 21, 275283.

612 Loiseau, A., Boudon, J., Mirjolet, C., Crehange, G., Millot, N., 2017. Taxane-Grafted Metal-Oxide Nanoparticles as a New Theranostic Tool against Cancer: The Promising Example of Docetaxel-Functionalized Titanate Nanotubes on Prostate Tumors. Adv. Healthc. Mater. 6 (16), 1700245.

616 Long, T.C., Saleh, N., Tilton, R.D., Lowry, G.V., Veronesi, B., 2006. Titanium dioxide (P25) produces reactive oxygen species in immortalized brain microglia (BV-2): implications for nanoparticle neurotoxicity. Environ. Sci. Technol., 40, 43464352.

620 Lupu, A., Popescu, T., 2013. The noncellular reduction of MTT tetrazolium salt by 621 $\mathrm{TiO}_{2}$ nanoparticles and its implications for cytotoxicity assays. Toxicol. In Vitro, $27,1445-1450$. 
Marel, A.K., Lizard, G., Izard, J.C., Latruffe, N., Delmas, D., 2008. Inhibitory effects of trans-resveratrol analogs molecules on the proliferation and the cell cycle progression of human colon tumoral cells. Mol. Nutr. Food Res., 52, 538-548.

Mirjolet, C., Boudon, J., Loiseau, A., Chevrier, S., Boidot, R., Oudot, A., Collin, B., Martin, E., Joy, P.A., Millot, N., 2017. Docetaxel-titanate nanotubes enhance radiosensitivity in an androgen-independent prostate cancer model. Int. J. Nanomed., 12, 6357-6363.

Mirjolet, C., Papa, A., Créhange, G., Raguin, O., Seignez, C., Paul, C., Truc, G., Maingon, P., Millot, N., 2013. The radiosensitization effect of titanate nanotubes as a new tool in radiation therapy for glioblastoma: a proof-of-concept. Radiother. Oncol., 108, 136-142.

Niu, L., Shao, M., Wang, S., Lu, L., Gao, H. \& Wang, J., 2008. Titanate nanotubes: preparation, characterization, and application in the detection of dopamine. J. Mater. Sci., 43, 1510-1514.

Nury, T., Zarrouk, A., Ragot, K., Debbabi, M., Riedinger, J.-M., Vejux, A., Aubourg, P., Lizard, G., 2017. 7-Ketocholesterol is increased in the plasma of X-ALD patients and induces peroxisomal modifications in microglial cells: Potential roles of 7-ketocholesterol in the pathophysiology of X-ALD. J. Steroid Biochem. Mol. Biol., 169, 123-136.

Ormerod, M.G., Collins, M.K., Rodriguez-Tarduchy, G., Robertson, D., 1992. Apoptosis in interleukin-3-dependent haemopoietic cells: Quantification by two flow cytometric methods. J. Immunol. Methods, 153, 57-65.

Papa, A.-L., Boudon, J., Bellat, V., Loiseau, A., Bisht, H., Sallem, F., Chassagnon, R., Bérard, V., Millot, N., 2015. Dispersion of titanate nanotubes for nanomedicine: comparison of PEI and PEG nanohybrids. Dalton Trans., 44, 739-746. 
648 Papa, A.-L., Maurizi, L., Vandroux, D., Walker, P., Millot, N., 2011. Synthesis of Titanate Nanotubes Directly Coated with USPIO in Hydrothermal Conditions: A New Detectable Nanocarrier. J. Phys. Chem. C, 115, 19012-19017.

Papa, A.-L., Millot, N., Saviot, L., Chassagnon, R., Heintz, O., 2009. Effect of Reaction Parameters on Composition and Morphology of Titanate Nanomaterials. J. Phys. Chem. C, 113, 12682-12689.

Papa, A.L., Dumont, L., Vandroux, D., Millot, N., 2013. Titanate nanotubes: towards a novel and safer nanovector for cardiomyocytes. Nanotoxicology, 7, 1131-42.

Paris, J., Bernhard, Y., Boudon, J., Heintz, O., Millot, N., Decréau, R.A., 2015. Phthalocyanine-titanate nanotubes: a promising nanocarrier detectable by optical imaging in the so-called imaging window. RSC Adv., 5, 6315-6322.

Perl, A., Gergely, P., Nagy, G., Koncz, A., Banki, K., 2004. Mitochondrial 660 hyperpolarization: a checkpoint of T-cell life, death and autoimmunity. Trends Immunol., 25, 360-367.

Pierzyńska-Mach, A., Janowski, P.A., Dobrucki, J.W., 2014. Evaluation of acridine orange, LysoTracker Red, and quinacrine as fluorescent probes for long-term tracking of acidic vesicles. Cytometry A, 85, 729-737.

Quent, V., Loessner, D., Friis, T., Reichert, J.C., Hutmacher, D.W., 2010. Discrepancies 666 between metabolic activity and DNA content as tool to assess cell proliferation in cancer research. J. Cell. Mol. Med., 14, 1003-1013.

Rehman, F., Zhao, C., Jiang, H., Wang, X., 2016. Biomedical applications of nanotitania in theranostics and photodynamic therapy. Biomater. Sci., 4, 40-54.

670 Rihane, N., Nury, T., M'rad, I., Mir, L., Sakly, M., Amara, S., Lizard, G., 2016. 671 Microglial cells (BV-2) internalize titanium dioxide $\left(\mathrm{TiO}_{2}\right)$. Environ. Sci. Pollut. Res. Int., 23, 9690-9699. 
673 Riss, T.L., Moravec, R.A., Niles, A.L., Duellman, S., Benink, H.A., Worzella, T.J.,

674

675

676

677

678

679

680

681

682

683

684

685

686

687

688

689

690

691

692

693

694

695

Minor, L., 2013 (updated 2016). Cell viability assays, in: Sittampalam, G.S., Coussens, N.P., Brimacombe, K., et al., editors. Assay Guidance Manual [Internet]. Bethesda (MD): Eli Lilly \& Company and the National Center for Advancing Translational Sciences; 2004-. Available from: https://www.ncbi.nlm.nih.gov/books/NBK144065/

Sabella, S., Carney, R.P., Brunetti, V., Malvindi, M.A., Al-Juffali, N., Vecchio, G., Janes, S.M., Bakr, O.M., Cingolani, R., Stellacci, F., 2014. A general mechanism for intracellular toxicity of metal-containing nanoparticles. Nanoscale, 6, 7052-7061.

Sabzi, M., Mirabedini, S.M., Zohuriaan-Mehr, J., Atai, M., 2009. Surface modification of $\mathrm{TiO}_{2}$ nano-particles with silane coupling agent and investigation of its effect on the properties of polyurethane composite coating. Prog. Org. Coat., 65, 222228.

Sallem, F., Boudon, J., Heintz, O., Séverin, I., Megriche, A., Millot, N., 2017. Synthesis and characterization of chitosan-coated titanate nanotubes: towards a new safe nanocarrier. Dalton Trans.. 46, 15386-15398

Saquib, Q., Al-Khedhairy, A.A., Siddiqui, M.A., Abou-Tarboush, F.M., Azam, A., Musarrat, J., 2012. Titanium dioxide nanoparticles induced cytotoxicity, oxidative stress and DNA damage in human amnion epithelial (WISH) cells. Toxicol. in Vitro, 26, 351-361.

Sruthi, S., Mohanan, P., 2016. Engineered zinc oxide nanoparticles; biological interactions at the organ level. Curr. Med. Chem., 23, 1-12. 
696 Suzuki, H., Toyooka, T., Ibuki, Y., 2007. Simple and easy method to evaluate uptake 697 potential of nanoparticles in mammalian cells using a flow cytometric light 698 scatter analysis. Environ. Sci. Technol., 41, 3018-3024.

699

700 
702

\begin{tabular}{c|cccc} 
& $\begin{array}{c}\text { Starting } \\
\text { degradation } \\
\text { temperature }\left({ }^{\circ} \mathbf{C}\right)\end{array}$ & $\begin{array}{c}\text { Mass loss } \\
\mathbf{( \% )}\end{array}$ & $\begin{array}{c}\text { Degraded } \\
\text { molecular weight }\end{array}$ & Molecule.nm $^{-2}$ \\
& & & $($ g.mol-1) & \\
\hline TiONts & 175 & 2.8 & 18 & $(10.6 \pm 1.5)$ OH, $\mathrm{n}=10$ \\
TiONts-APTES & 160 & 10.3 & 58 & $(7.3 \pm 0.5)$ APTES, $\mathrm{n}=7$
\end{tabular}

703 Table 1. Results of mass loss and hydroxyl groups density and grafting ratio of bare

704 TiONts and TiONts-APTES respectively ( $\mathrm{n}$ is the number of syntheses realized before 705 pooling the different batches, they allow to evaluate the reproducibility of our 706 syntheses).

707

\begin{tabular}{c|cccccc}
\hline Atomic concentration (\%) & $\mathbf{C}_{1 \mathbf{s}}$ & $\mathbf{O}_{1 \mathbf{s}}$ & $\mathbf{N a}_{\text {KLL }}$ & $\mathbf{T i}_{2 \mathbf{p}}$ & $\mathbf{N}_{\mathbf{1 s}}$ & $\mathbf{S i}_{2 \mathbf{p}}$ \\
\hline TiONts & 7.3 & 58.7 & 13.5 & 20.5 & - & - \\
\% Elements TiONts / Ti & 0.3 & 2.9 & 0.7 & 1.0 & - & - \\
\hline TiONts-APTES & 11.2 & 56.8 & 5.7 & 21.5 & 2.3 & 2.5 \\
\% Elements TiONts-APTES / Ti & 0.5 & 2.6 & 0.3 & 1.0 & 0.1 & 0.1 \\
\hline
\end{tabular}

708 Table 2. XPS elemental analyses and their corresponding ratio to titanium of bare 709 TiONts and TiONts-APTES. 


\section{$711 \quad$ Figures}

712

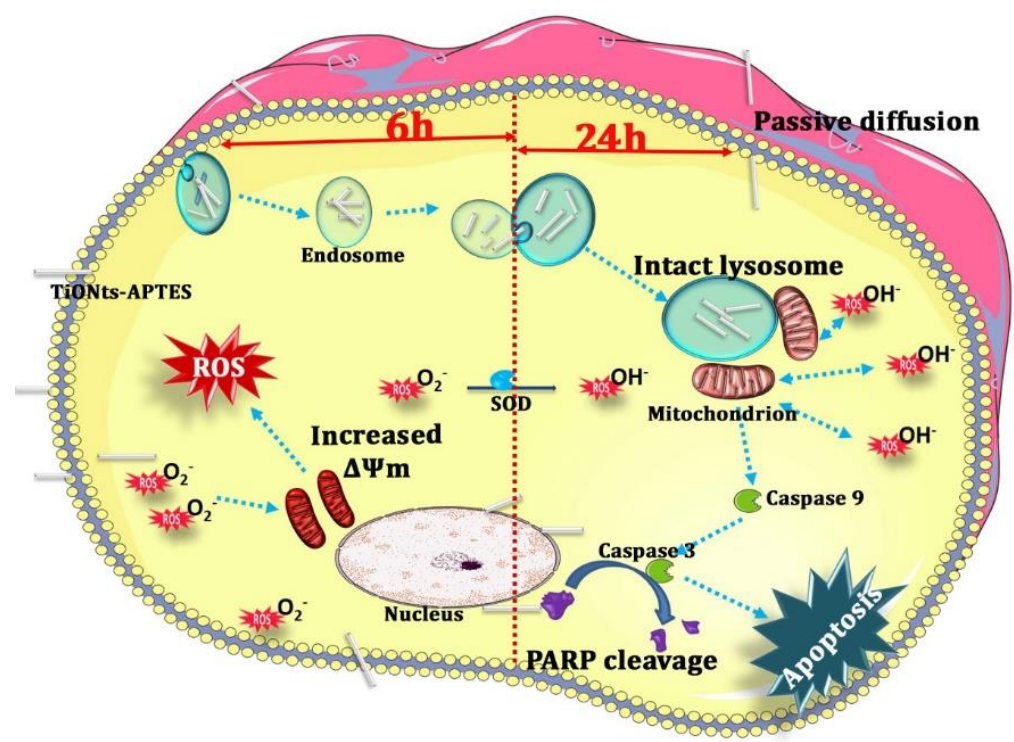

713 Graphical abstract: (3-aminopropyl) triethoxysilane (APTES) functionalized titanate

714 nanotubes (named TiONts on the scheme) enter the BV-2 cell both via endocytosis and

715 passive diffusion. Inside cell, TiONts-APTES are capable of inducing superoxide

716 radicals which later get converted to peroxides by SOD activity. TiONts-APTES

717 interact with mitochondria to induce a transient increase in $\Delta \Psi \mathrm{m}$ which further gives

718 way to mitochondria mediated ROS production. TiONts-APTES do not affect

719 lysosomal integrity or cell cycle pattern. At high concentration TiONts-APTES

720 probably induce caspase-mediated apoptosis in BV-2 cells leading to PARP cleavage. 


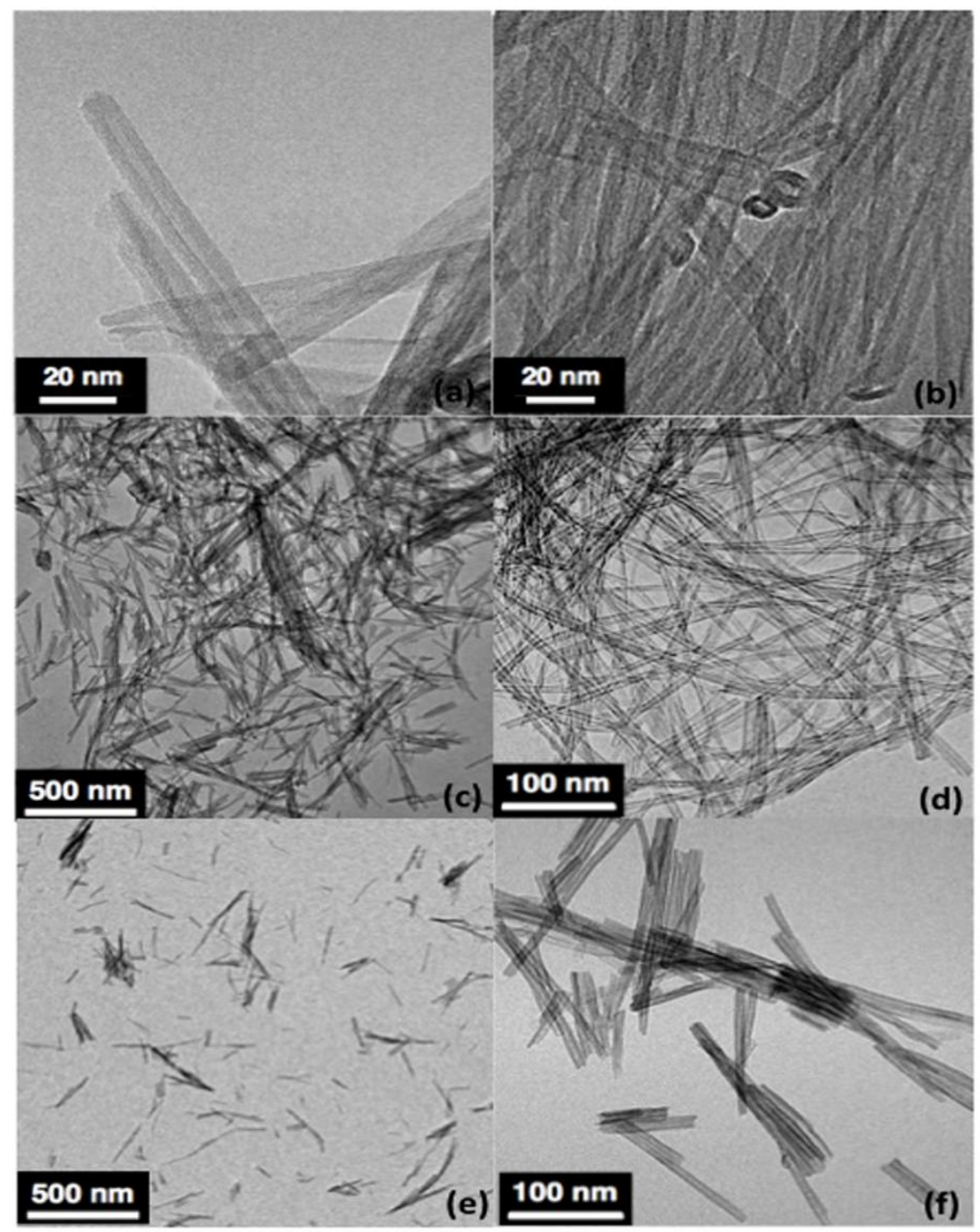

722 Figure 1. TEM images highlight (a-b) the formation of bare TiONts and the evolution of

723 TiONts dispersion (c-d) before and (e-f) after APTES grafting. 

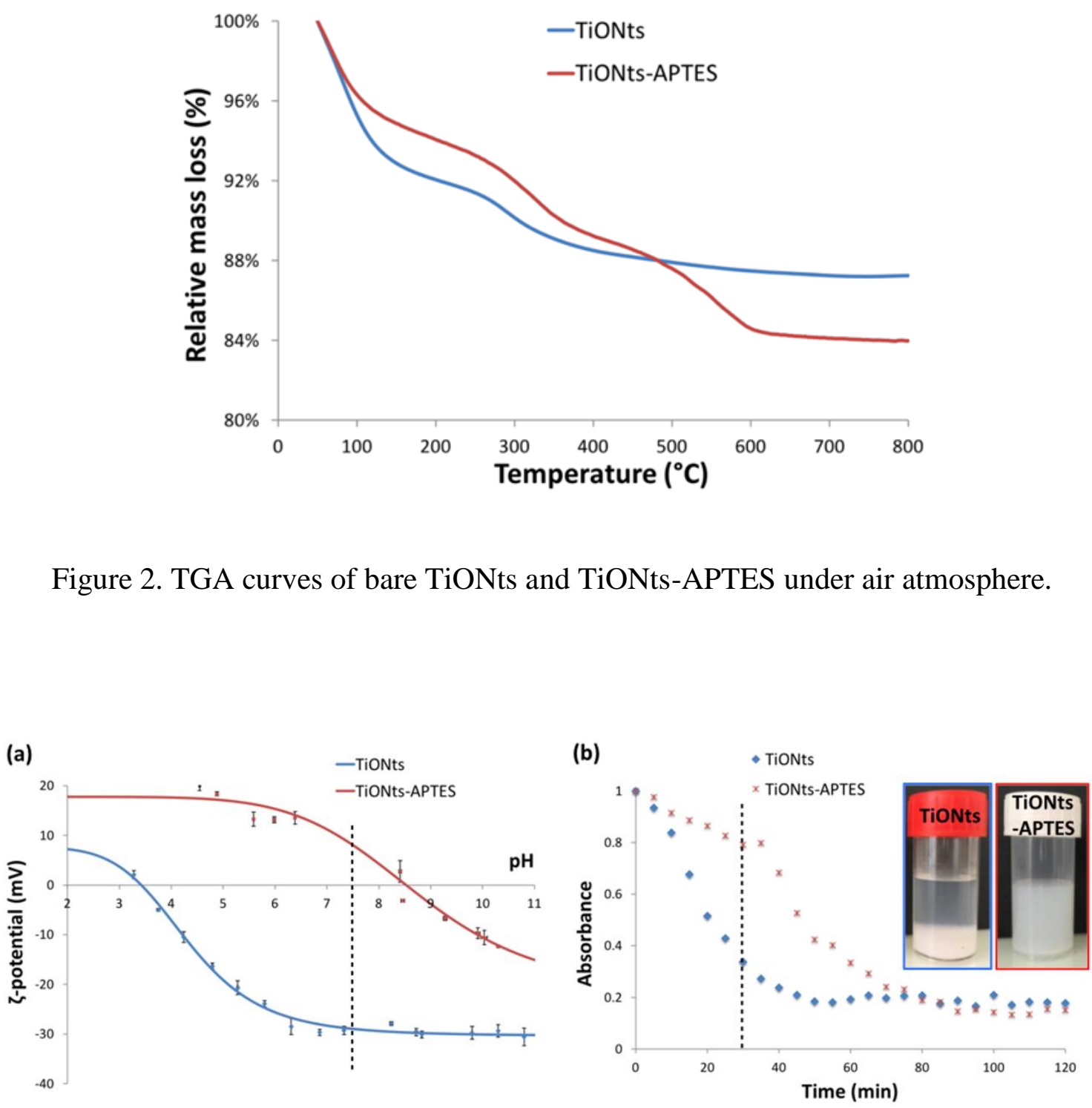

729 Figure 3. (a) $\zeta$ potential curves of bare TiONts and TiONts-APTES (the vertical dashed

730 line corresponds to the physiological pH). (b) Colloidal stability of bare TiONts and

731 TiONts-APTES (PBS $0.1 \mathrm{M}$; pH 7.4) over $120 \mathrm{~min}$ following their absorbance

732 at $600 \mathrm{~nm}$ by turbidimetry. The pictures of TiONts (left) and TiONts-APTES (right)

733 suspensions in PBS (0.1 M; pH 7.4) correspond to the vertical dashed line at $30 \mathrm{~min}$. 


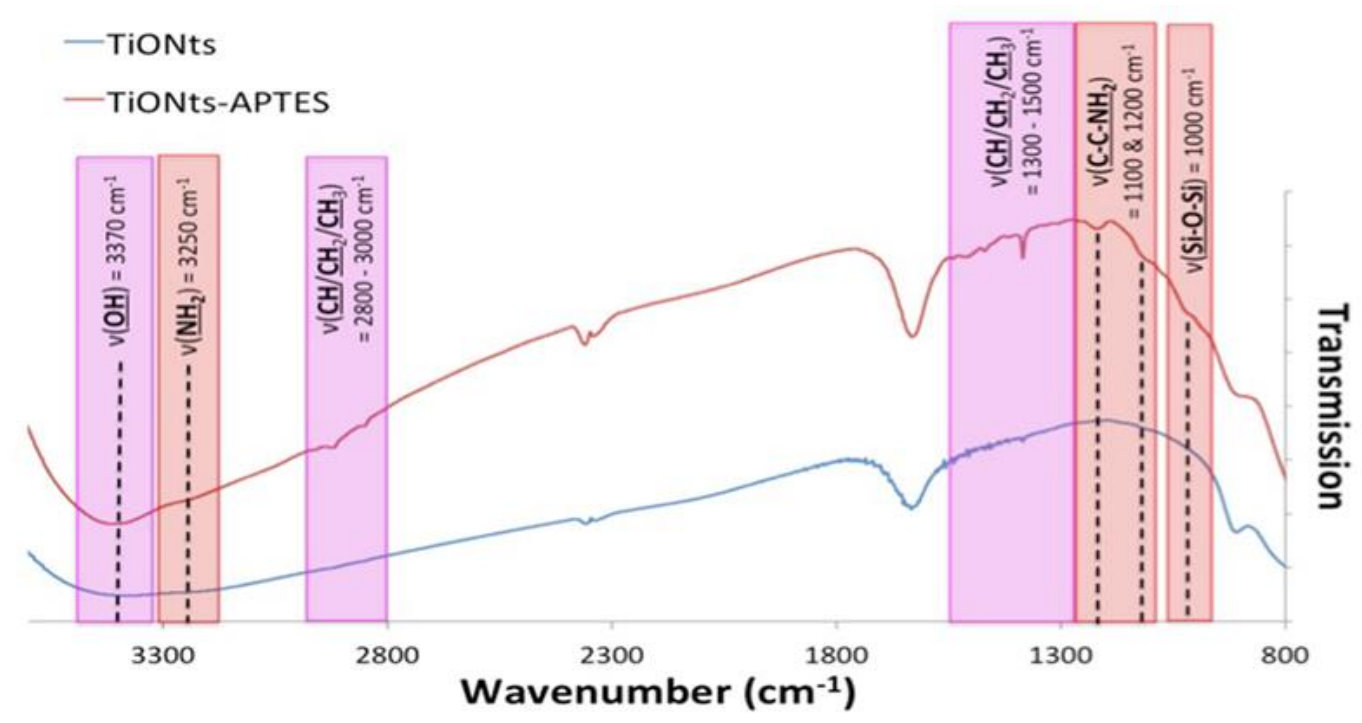

Figure 4. FT-IR spectra of bare TiONts and TiONts-APTES. Red vibrational bands

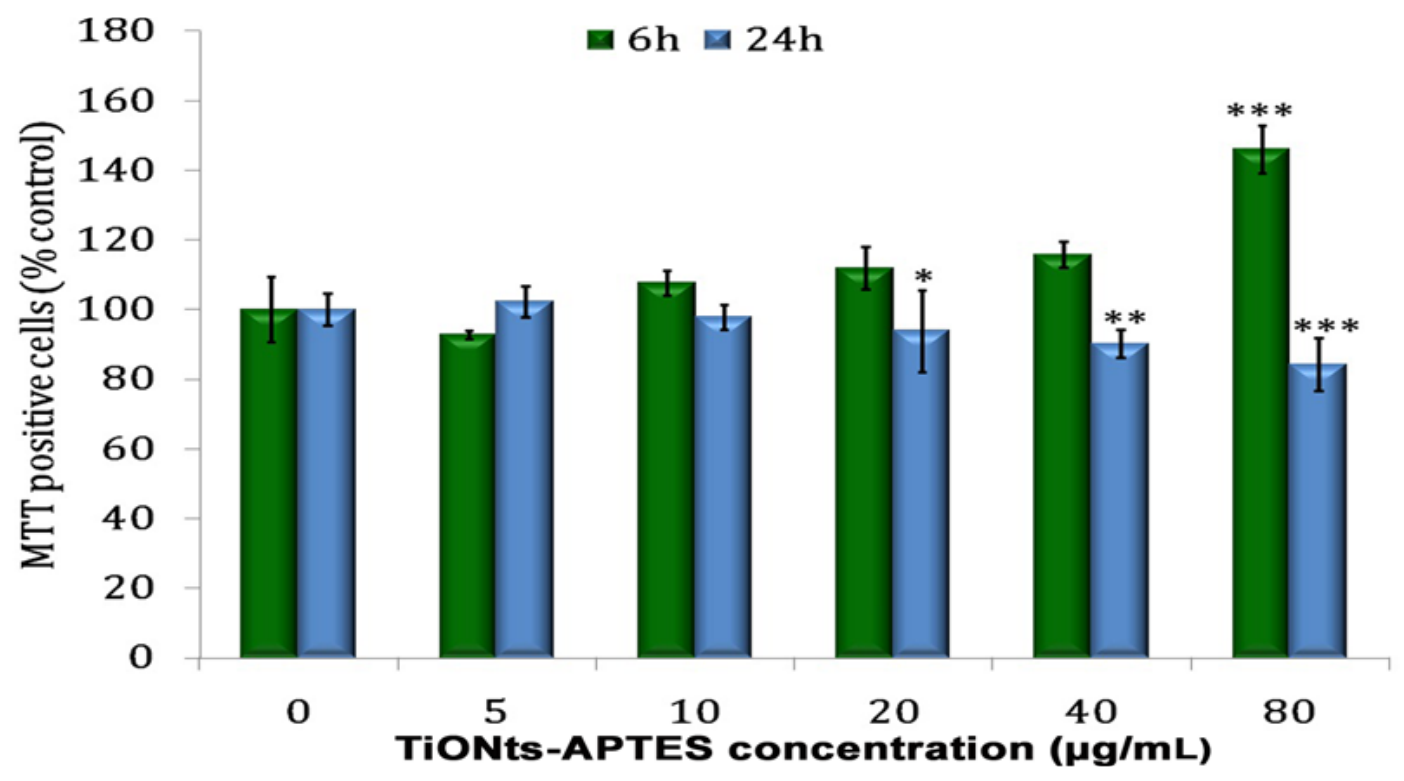

740 Figure 5. (a) Dose response and cytotoxicity in BV-2 cells exposed to TiONts-APTES

741 for 6 and $24 \mathrm{~h}$ indicated by percentage MTT positive cells. Data represents mean \pm SD

742 of three independent experiments. Asterisks denote statistically significant differences

743 compared to the control $(* \mathrm{p}<0.05, * * \mathrm{p}<0.01$ and $* * * \mathrm{p}<0.001)$. 

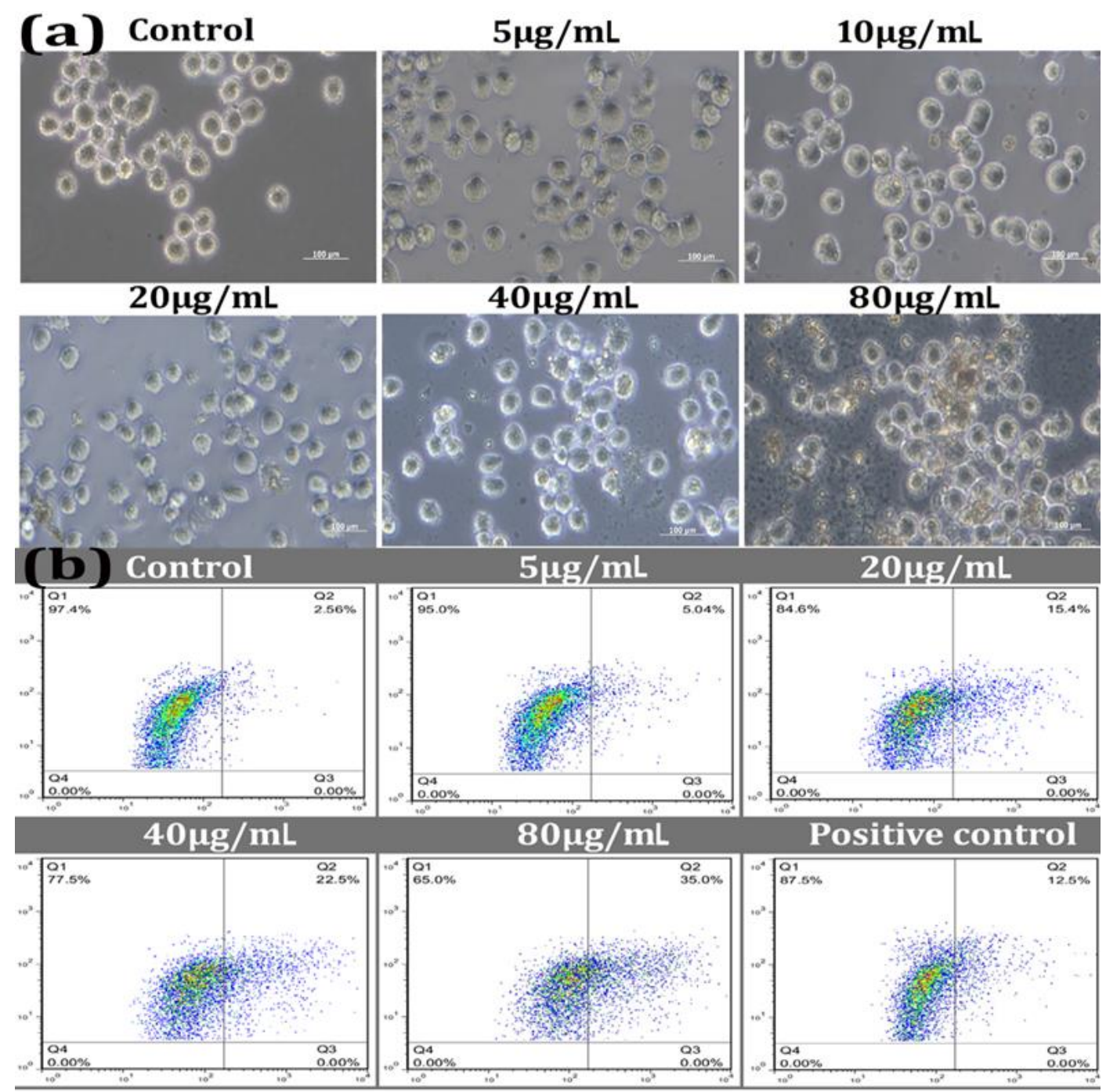

$80 \mu \mathrm{g} / \mathrm{mL}$

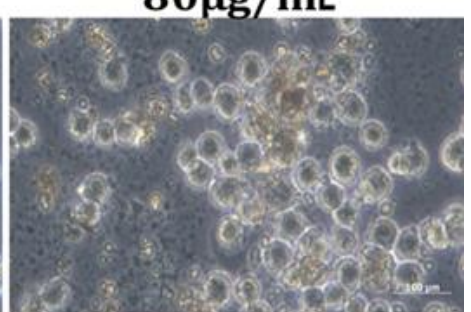

746
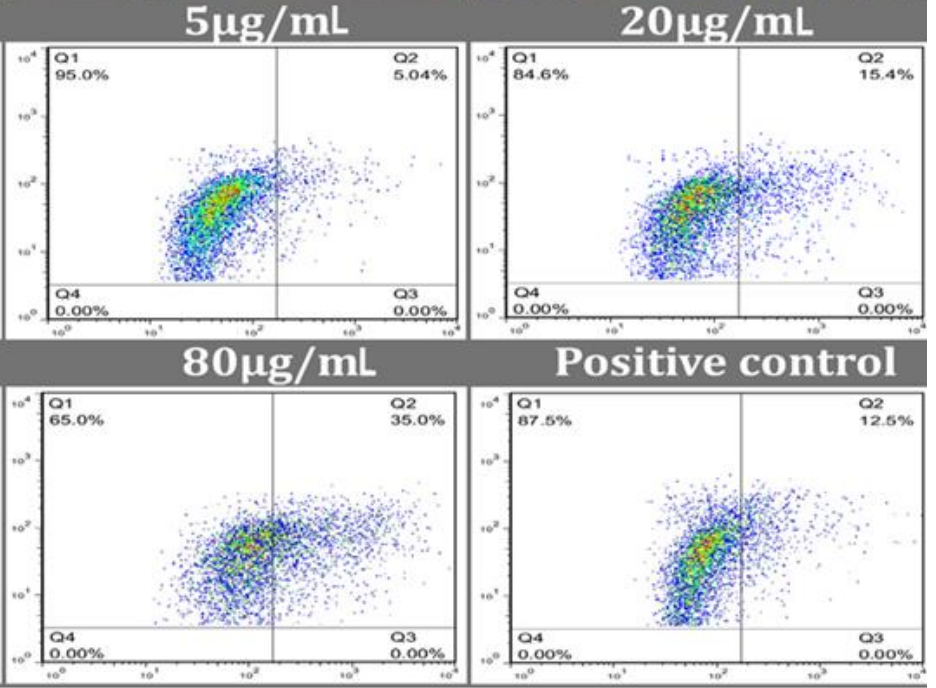

747 Figure 6. (a) Cell morphology analysis of BV-2 cells exposed to TiONts-APTES for

$74824 \mathrm{~h}$. Scale bar represents $100 \mu \mathrm{m}$. As the highest concentration used the nanoparticles

749 sediments could be observed. (b) Cellular uptake of TiONts-APTES by BV-2 cells:

750 cells were exposed to TiONts-APTES for $6 \mathrm{~h}$ and the increase in side scatter (SSC) with

751 respect to forward scatter (FSC) was measured. 7-ketocholesterol-treated cells were used as positive control. All the cellular debris were gated out to represent the data. 


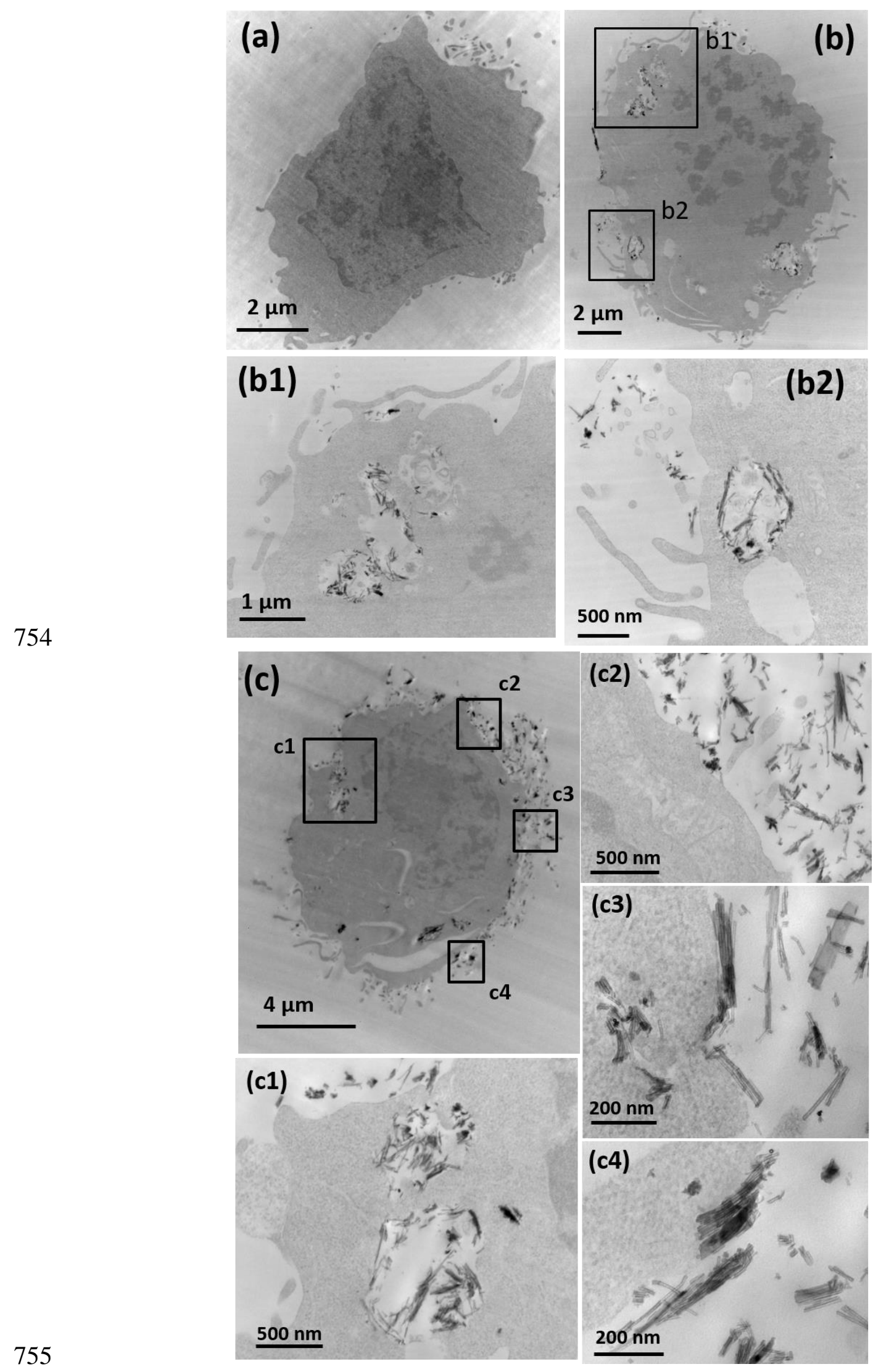




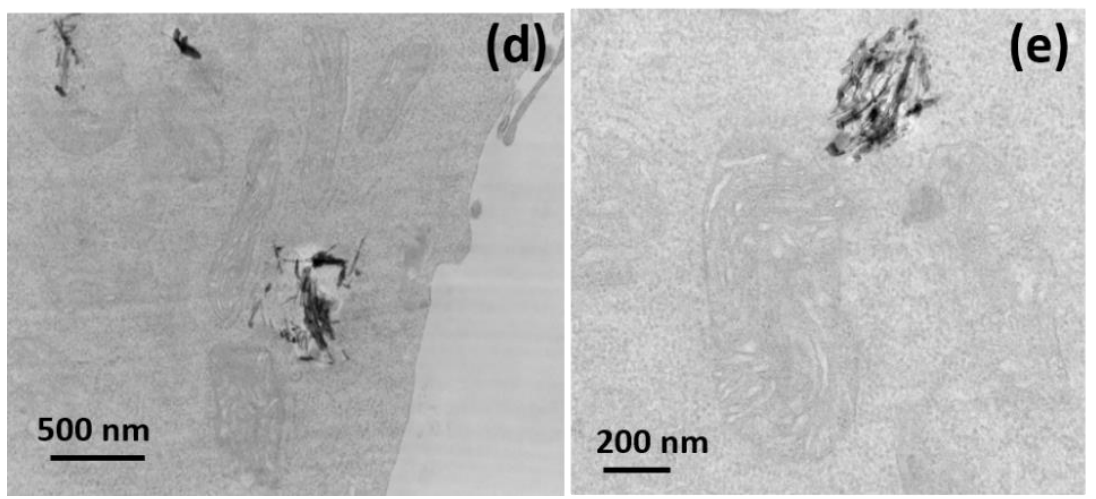

757 Figure 7 : TEM images of (a) BV-2 control cells, (b,b1,b2) BV-2 cells treated with $75820 \mu \mathrm{g} / \mathrm{mL}$ of TiONts-APTES without amiloride (c,c1,c2,c3,c4) BV-2 cells treated with $75920 \mu \mathrm{g} / \mathrm{mL}$ of TiONts-APTES and $100 \mu \mathrm{M}$ of amiloride, incubated for $24 \mathrm{~h}$ (d) 760 endocytosis vesicle surrounded by four mitochondria (e) endocytosis vesicle in contact 761 with mitochondria.
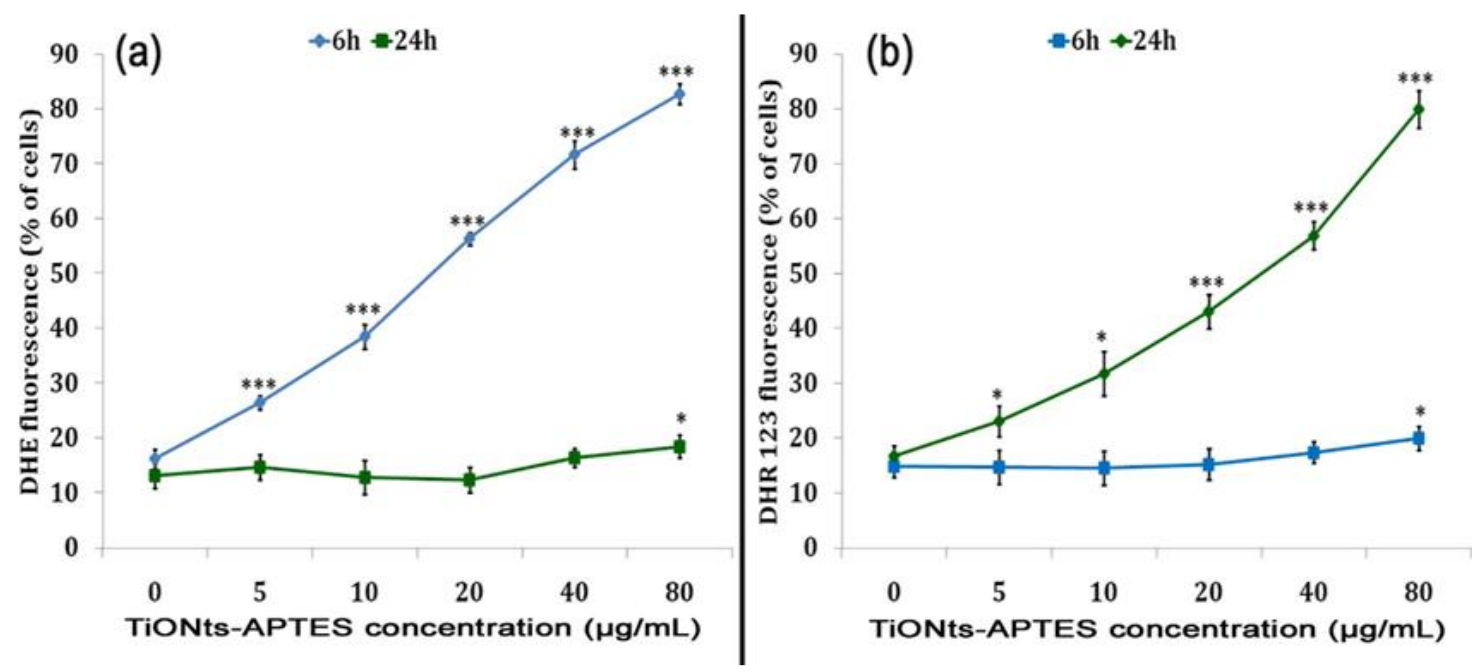

764 Figure 8. ROS generation in BV-2 cells exposed to TiONts-APTES for 6 and 24 h. (a)

765 Superoxide radical formation (b), hydrogen peroxide radical formation. Data represents

766 mean \pm SD of three independent experiments. Asterisks denote statistically significant

767 differences compared to control $(* \mathrm{p}<0.05, * * \mathrm{p}<0.01$ and $* * * \mathrm{p}<0.001)$. 


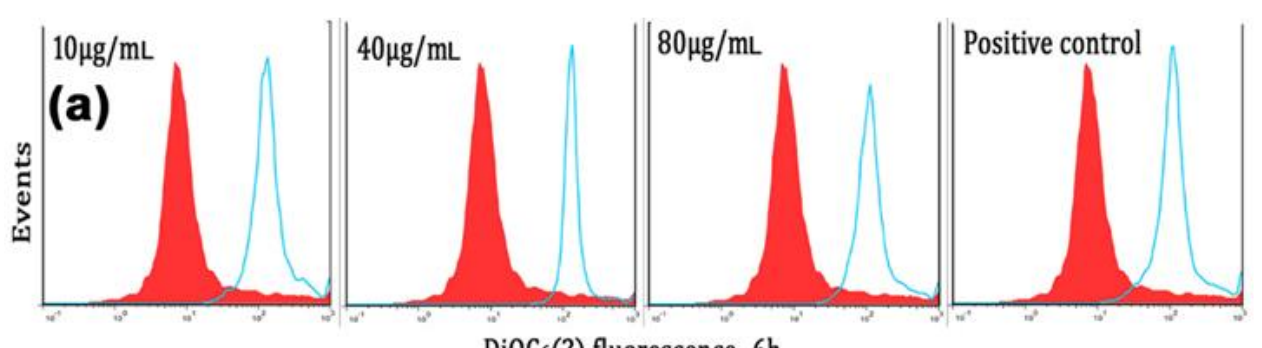

$\mathrm{DiOC}_{6}(3)$ fluorescence- $6 \mathrm{~h}$

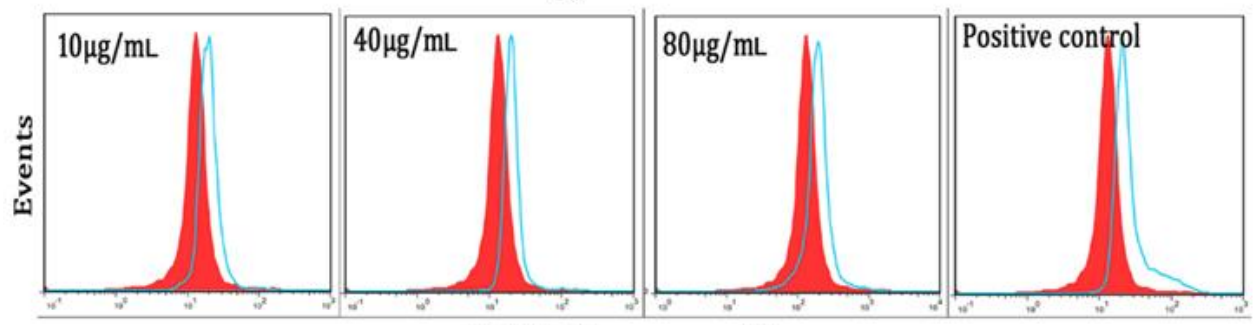

Di0C6(3) fluorescence- $24 \mathrm{~h}$
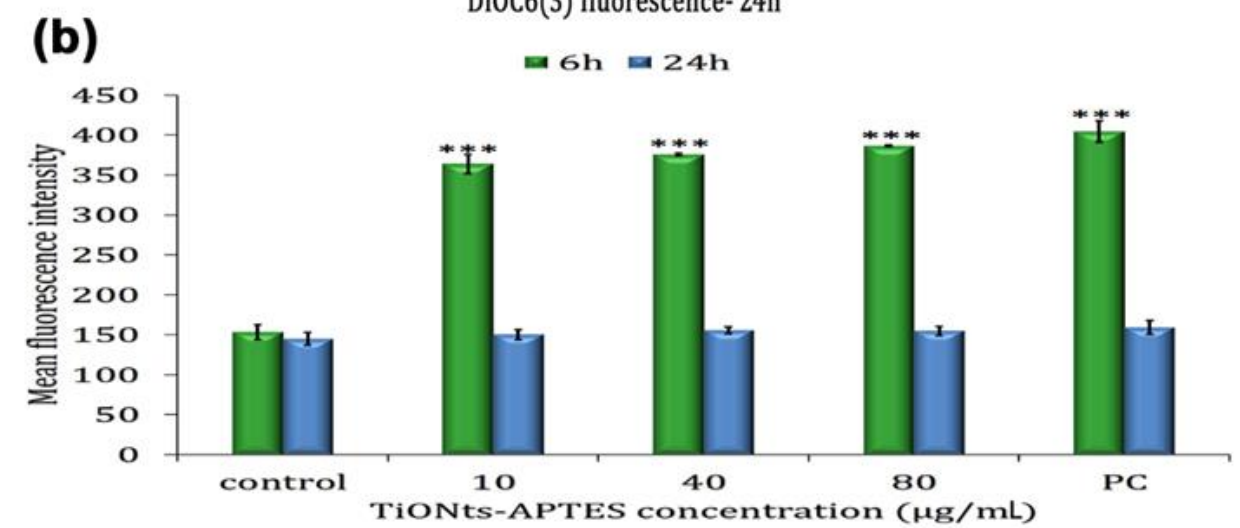

770 Figure 9. (a) Transmembrane mitochondrial potential in BV-2 cells exposed to TiONts-

771 APTES at 6 and 24 h. Cells incubated with $4 \%$ paraformaldehyde were used as positive

772 control (PC). Red solid peaks represent $\mathrm{DiOC}_{6}(3)$ intensity of untreated control while

773 blue tinted peaks represent treated groups. The gated population includes both dead and

774 viable cells. (b) Flow cytometric quantification of transmembrane mitochondrial

775 potential $(\Delta \Psi \mathrm{m})$. Data shown represent mean $\pm \mathrm{SD}$ of three independent experiments.

776 Asterisks denote statistically significant differences compared to control (*** $\mathrm{p}$ value $777<0.001)$. 


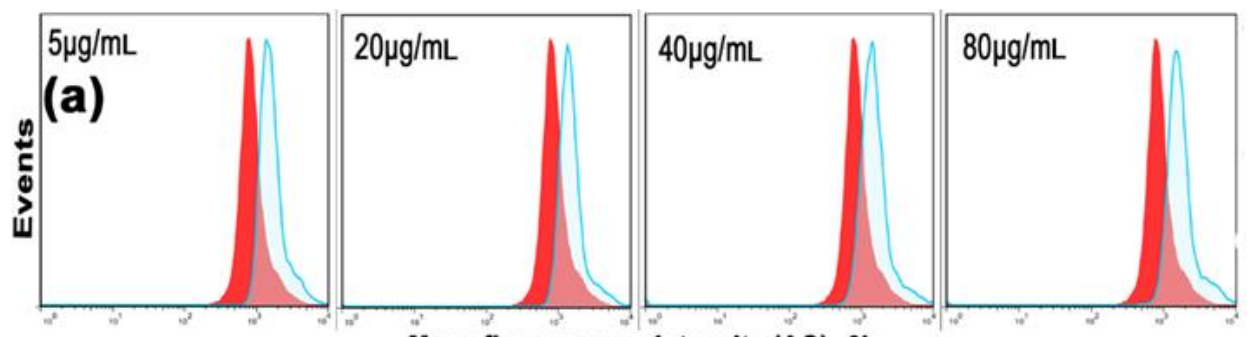

Mean fluorescence intensity (AO)- $6 \mathrm{~h}$

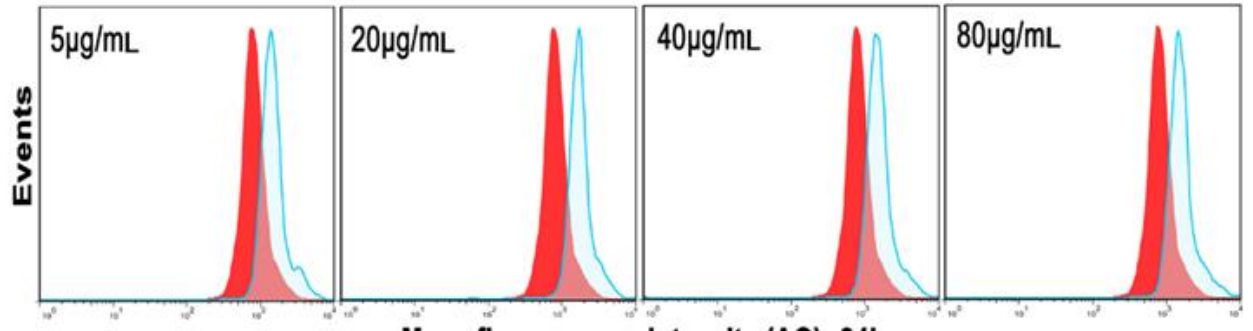

(b)

Mean fluorescence intensity (AO)- $24 \mathrm{~h}$

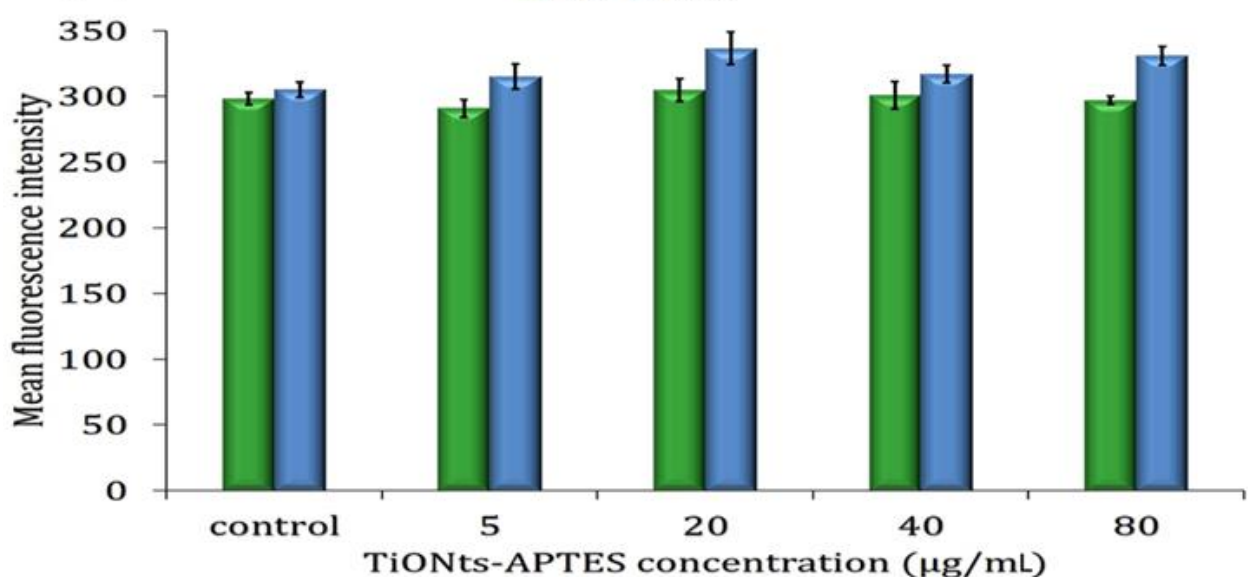

780 Figure 10. (a) Lysosomal membrane integrity of BV-2 cells exposed to TiONts-APTES

781 for 6 and $24 \mathrm{~h}$. The red solid peaks denote AO intensity in control population while blue

782 tinted peaks represent treatment groups. The gated population includes both viable and

783 dead cells. (b) Flow cytometric quantification of the lysosomal membrane integrity.

784 Data shown represent mean \pm SD of three independent experiments. 


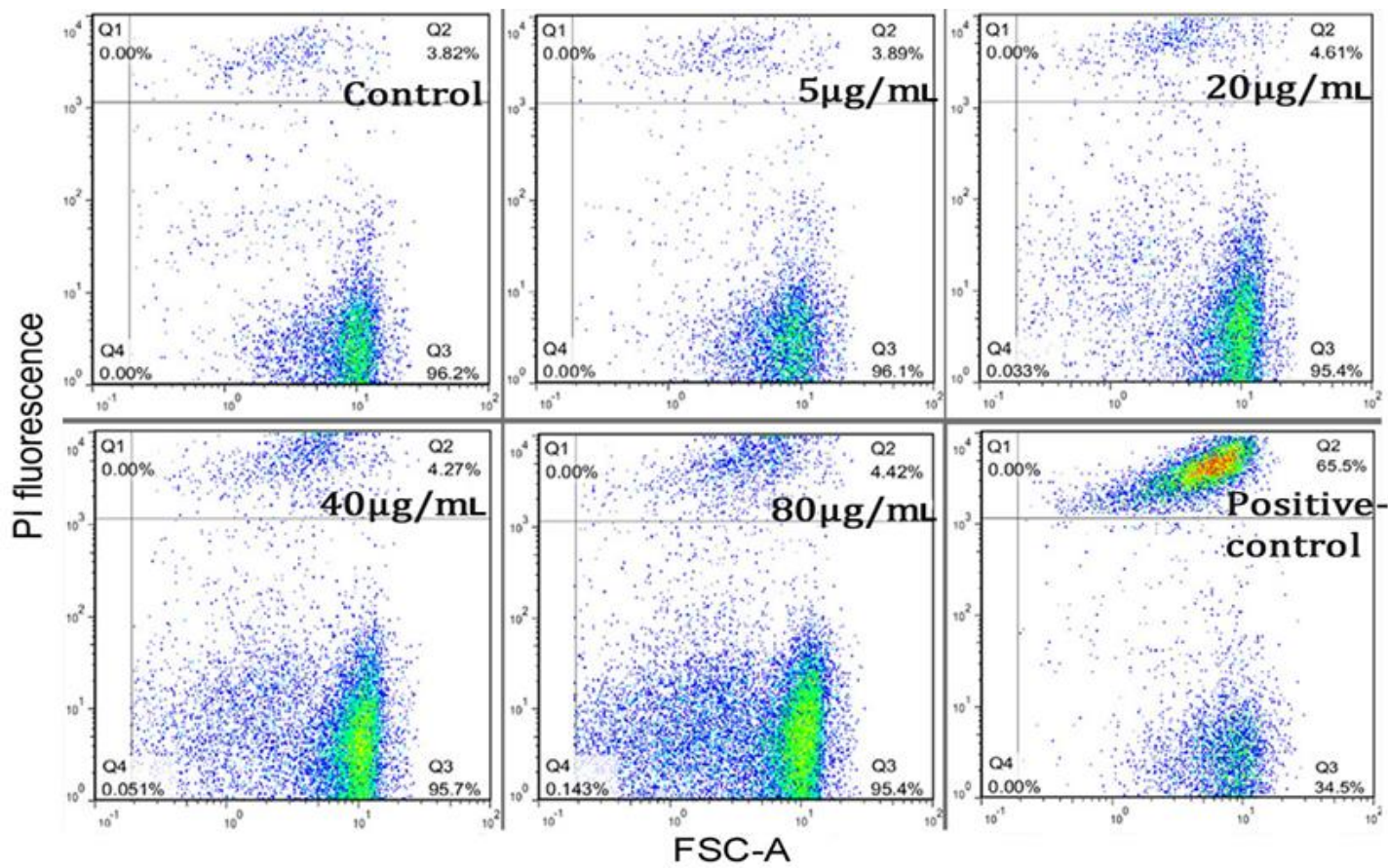

787 Figure 11. Plasma membrane integrity in BV-2 cells exposed to TiONts-APTES for 24

788 h. 7-ketocholesterol treated cells were used as positive control. The gating was done

789 with respect to PI fluorescence of positive control. Gated population includes both live 790 and dead cells. $\mathrm{n}=3$.
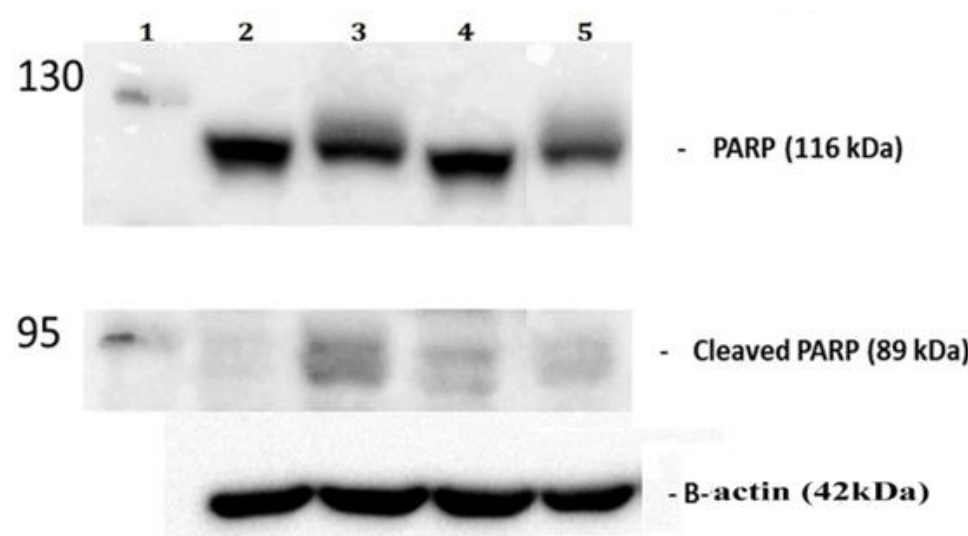

Figure 12. PARP cleavage assay in BV-2 cells exposed to TiONts-APTES for $24 \mathrm{~h}$.

793 Lane 1: protein marker, Lane 2: control cells, Lane3: control cells pre-treated with Z-

794 Fa-FMK, lane 4: TiONts-APTES $(80 \mu \mathrm{g} / \mathrm{mL})$, lane 5: $80 \mu \mathrm{g} / \mathrm{mL}$ TiONts-APTES pretreated with Z-Fa-FMK. 

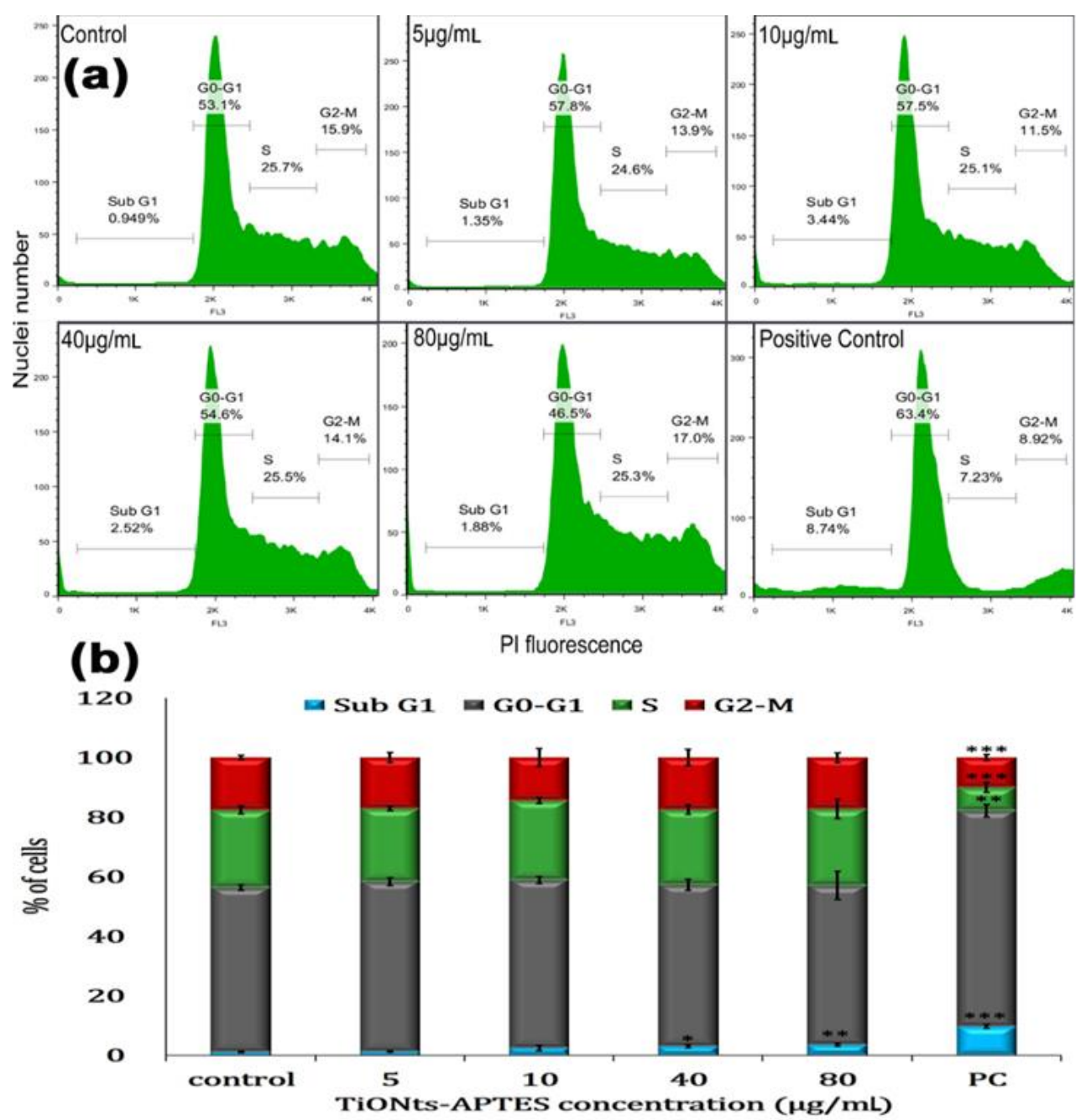

797 Figure 13. (a) Cell cycle analysis of BV-2 cells exposed to TiONts-APTES for 24 h. (b)

798 quantification of the cell cycle analysis. 7-ketocholestrol-treated cells were used as

799 positive control (PC). All the cellular debris has been gated out to represent the data.

800 Data shown represent mean \pm SD of three independent experiments. Asterisks denote

801 statistically significant differences compared to control ( $* \mathrm{p}$ value $<0.05, * * \mathrm{p}$ value $<$ $802 \quad 0.01$ and $* * * \mathrm{p}$ value $<0.001)$ 